Doi: www.doi.org/10.25130/tjaes.17.55.1.19

دور ممارسات إدارة الموارد البشرية الخضراء في تعزيز الريادة الاستراتيجية

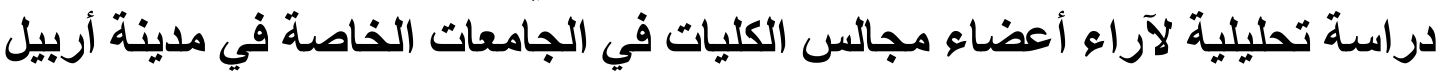

الباحث: دهام صابر حمد

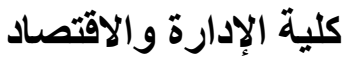

جامعة صلاح الدين/أربيل

Daham0071@gmail.com

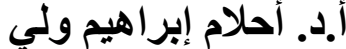

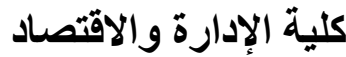

جامعة صلاح الدين/أربيل

ahlam.wali@su.edu.krd

هدف البحث إلى تحليل علاقة وتأثنير ممارسات إدارة الموارد البشرية الخضر اء للقيادات

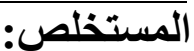

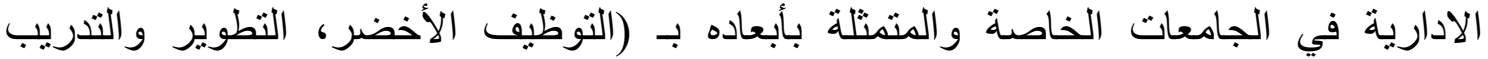

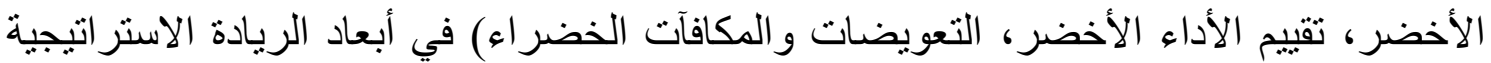

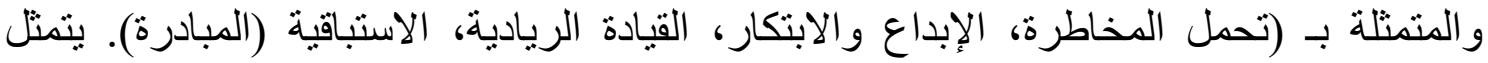
الإطار العام للار اسة بمشكلة الدر اسة والتي حددت بإثارة تساؤلات عدة حول طبيعة العلاقة و التأثير

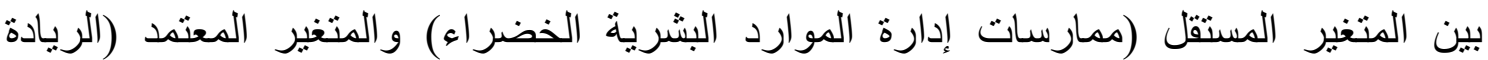
الاستراتيجية) و لأجل ذلك تم تصميم مخطط فرضي للار اسة عبر عن مجمو عة من الفرضيات الرئيسة، ولأجل التأكد من صحة الفرضيات خضعت جميعها لاختبار ات متعددة وقد استخدمت من الدر اسة استمارة الاستبانة كأداة للحصول على البيانات التهل انتهجت الدر اسة المنهج الوصفي التحليلي،

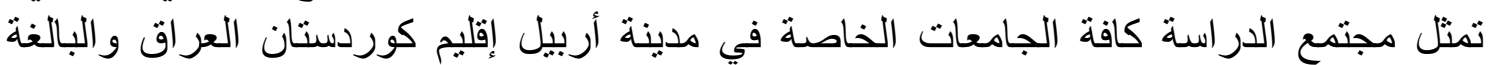
عدده (7) الجامعات الخاصة، و عينة الدر اسة بلغت عددها (7) من الجامعات الخاصة، أما الأفر اد المستجيبين فبلغ عددهم (84) عضواً من أعضاء مجالس الكليات من إجمالي القادة في العينة

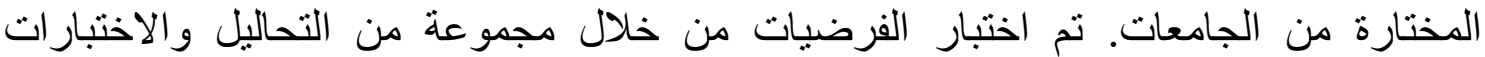

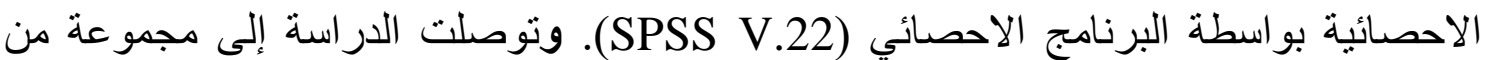

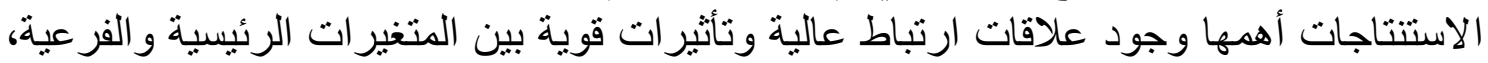

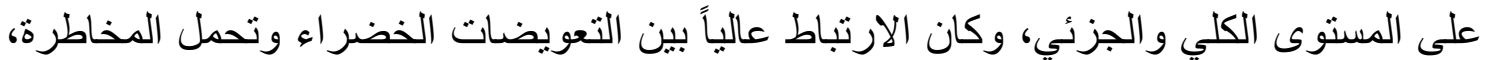

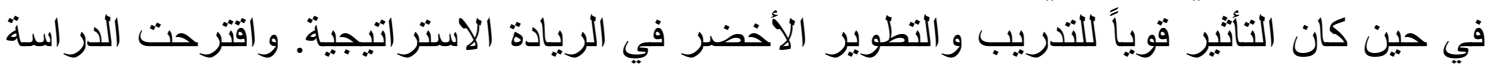

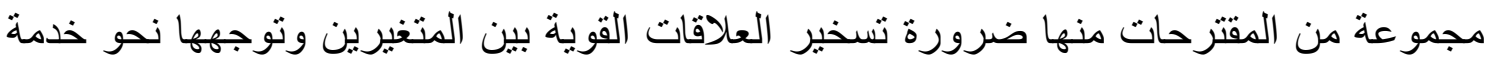

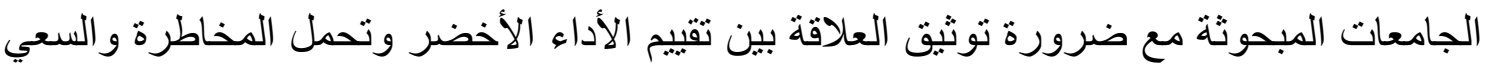

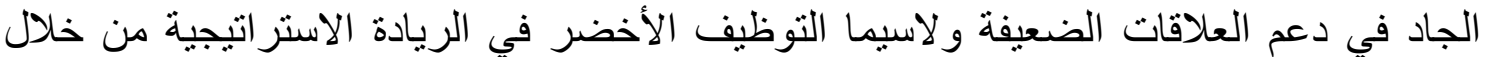

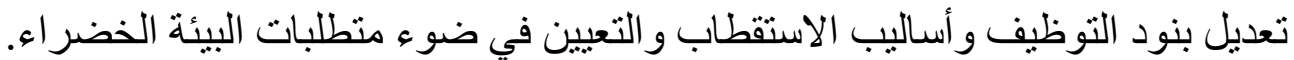

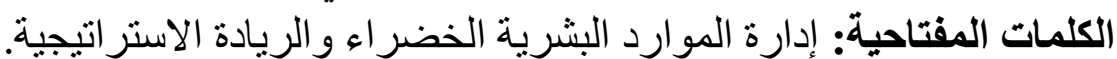

\title{
The role of green human resource management practices in
} enhancing strategic leadership/An analytical study of the opinions of faculty council members in private universities in Erbil

Prof. Dr. Ahlam Ibrahim Wali

College of Administration and Economics

Salahaddin University/Erbil
Researcher: Daham Sabir Hamad College of Administration and Economics Salahaddin University/Erbil

\section{Abstract:}

The present study aimed to analyze the relationship and impact of green human resource management for administrative leaders in private universities, represented by 
its dimensions (green employment, development and green training, green performance evaluation, green compensation and rewards) in the dimensions of strategic leadership, represented by (risk tolerance, creativity and innovation, and entrepreneurial leadership), Proactive (initiative).The general framework of the study represents the problem of the study, which with its effects has identified several questions about the nature of the relationship and the impact and the contrast between the independent variable (green human resource management) and the adopted variable (strategic leadership). The validity of all the hypotheses were subjected to multiple tests and the study used a questionnaire form as a tool to obtain the data. The study followed the descriptive and analytical approach, as the main and sub-variables were described, as well as to analyze the relationships and influence between the variables. As for the individual respondents, their number reached (84) members of college boards out of the total leaders in the selected sample of universities. The hypotheses were tested through a set of statistical analyzes and tests using the computer program (SPSS V.22). The study reached a set of conclusions, the most important of which is the presence of high correlations and strong influences between the main and sub-variables, at the macro and micro level, and the correlation was high between green compensation and risk tolerance, while the impact was strong for training and green development in strategic leadership. The study suggested a set of proposals in light of the conclusions, including the necessity of harnessing the strong relationships between the two variables and directing them towards serving the researched universities with the necessity of documenting the relationship between evaluating green performance and taking risks and striving seriously to support weak relationships, especially green employment in strategic leadership by modifying employment items and methods of recruitment.

Keywords: Green human resource management and strategic leadership.

إن من أهم القضايا الرئيسية التي تستحوذ على اهتمام العالم في وقتنا الحالي هي حماية

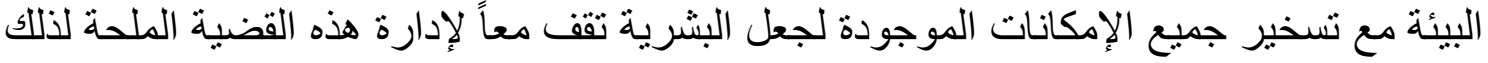

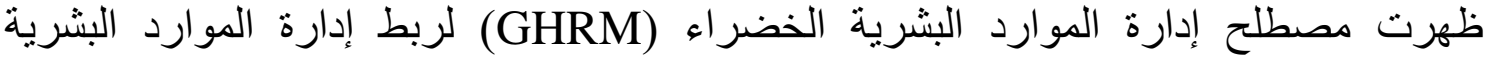

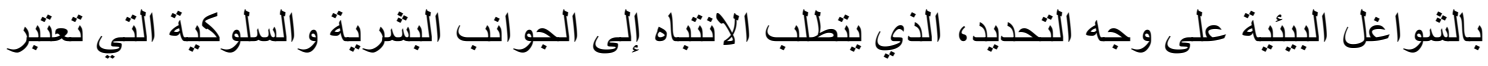

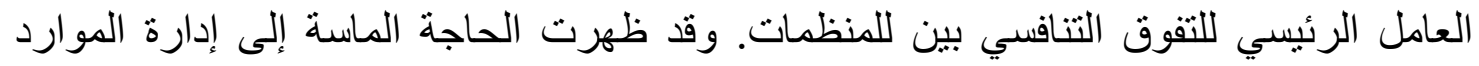
البشرية الخضر اء وممار ساتها استجابة إلى مبادر ات المنظمات الدولية التي تهتم بالحفاظ على البيئة

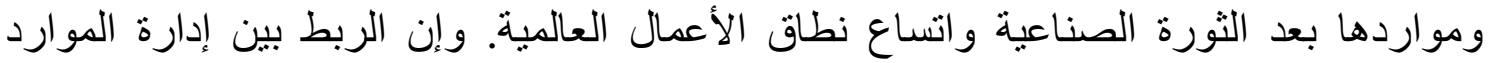

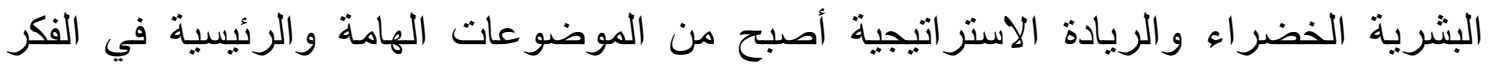
الإداري الحديث. فمنظمات الأعمال اليوم تدرك الآن أنه يتعين عليها تطوير ضمير اجتماعي قوي

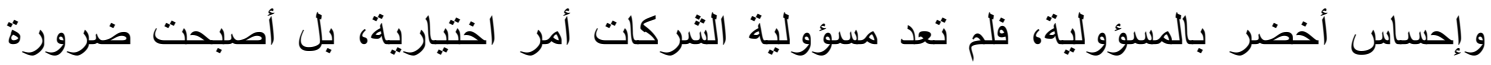

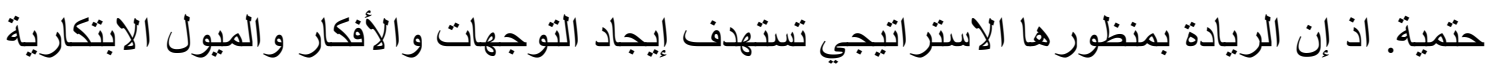

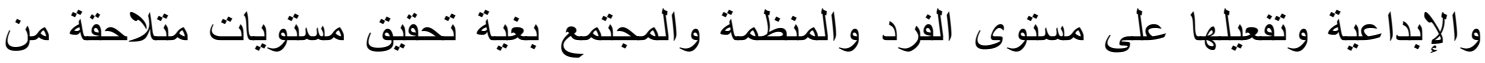

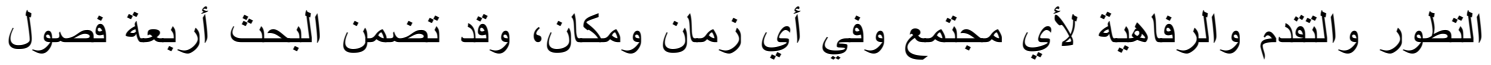


تضمن الفصل الأولى الإطار المنهجي وتناول الفصل الثاني الجانب النظري وخصص الفصل

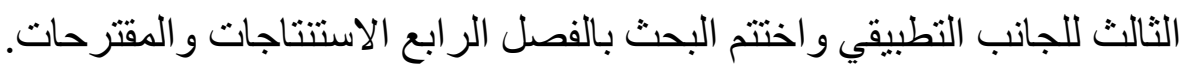

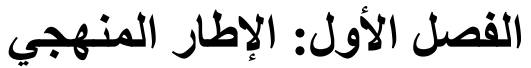

أولاً. مشكلة البحث: أن أحد الشروط الأساسية لنجاح أي منظمة مقترن بنجاح دور مواردها لألها

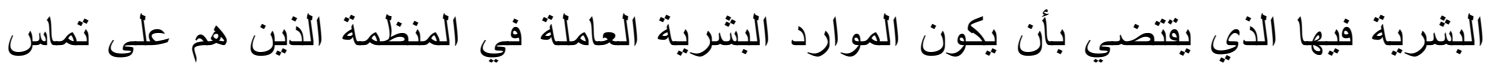

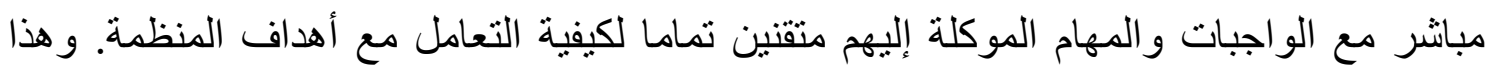

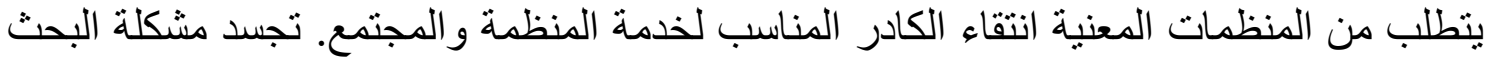

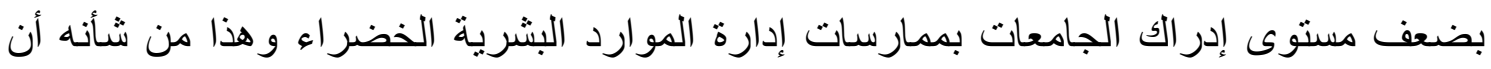

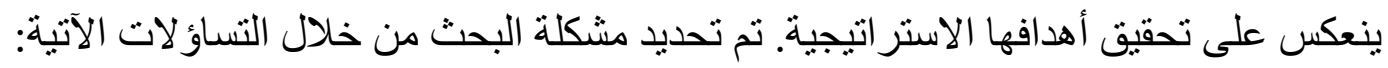

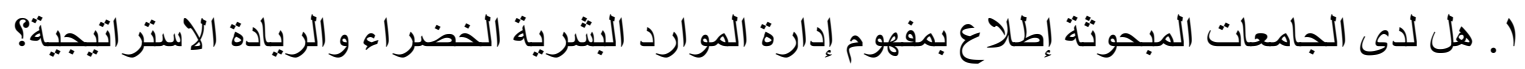

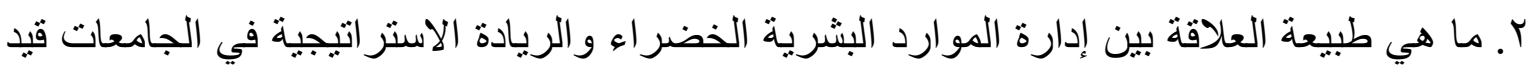

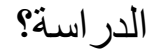
r. ماهي نأثير إدارة الموارد البشرية الخضراء في تحقيق الريادة الاستراتيجية في الجامعات قيد

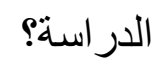
ثانياً. أهمية البحث: تبرز أهمبة البحث من خلال النقاط التالية:

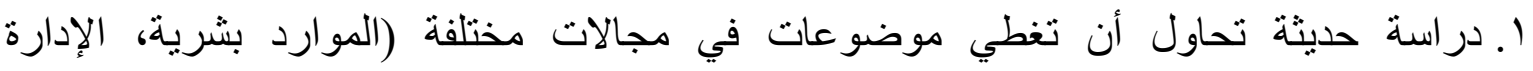

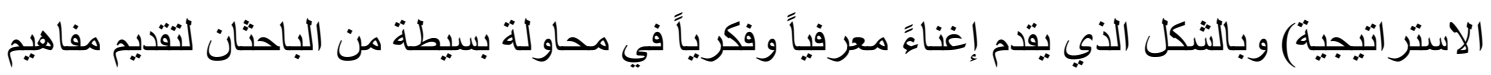

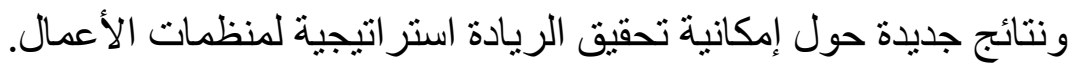

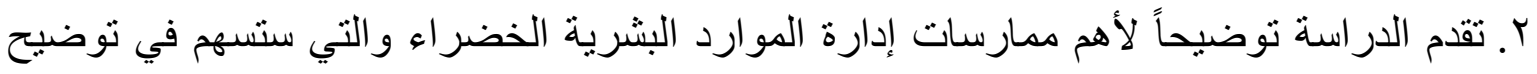

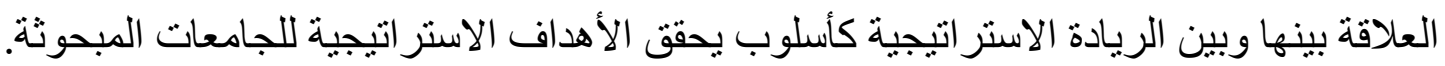

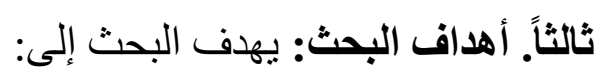

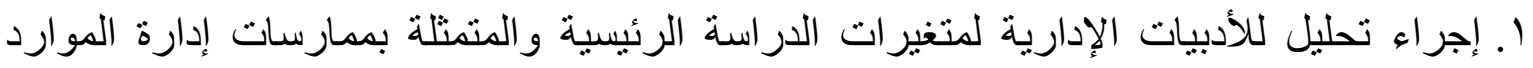

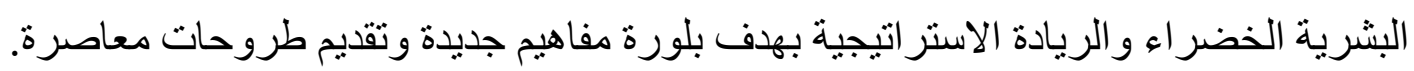

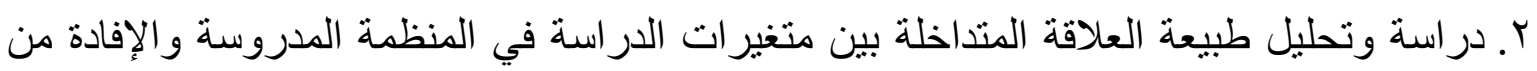

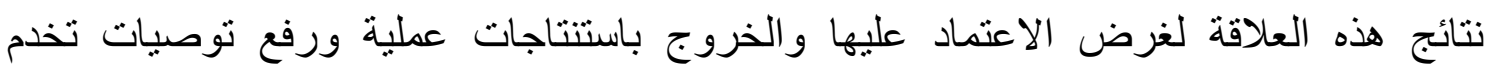

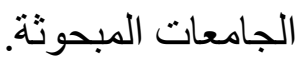
r. تصميم مخطط فرضي للار اسة والسعي نحو اختبار الفرضيات المنبنقة منها وتعميم نتائجها على الفى القطاع التعليمي في إقليم كوردستان العراق. لإني

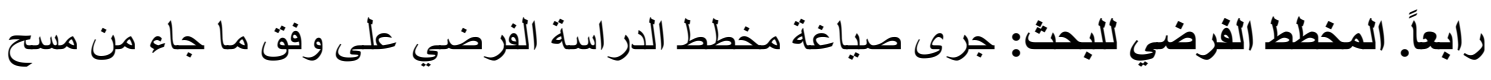

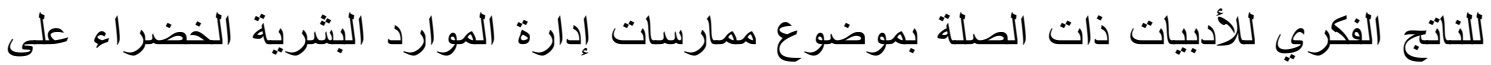
تحقيق الريادة الاستر اتيجية. 


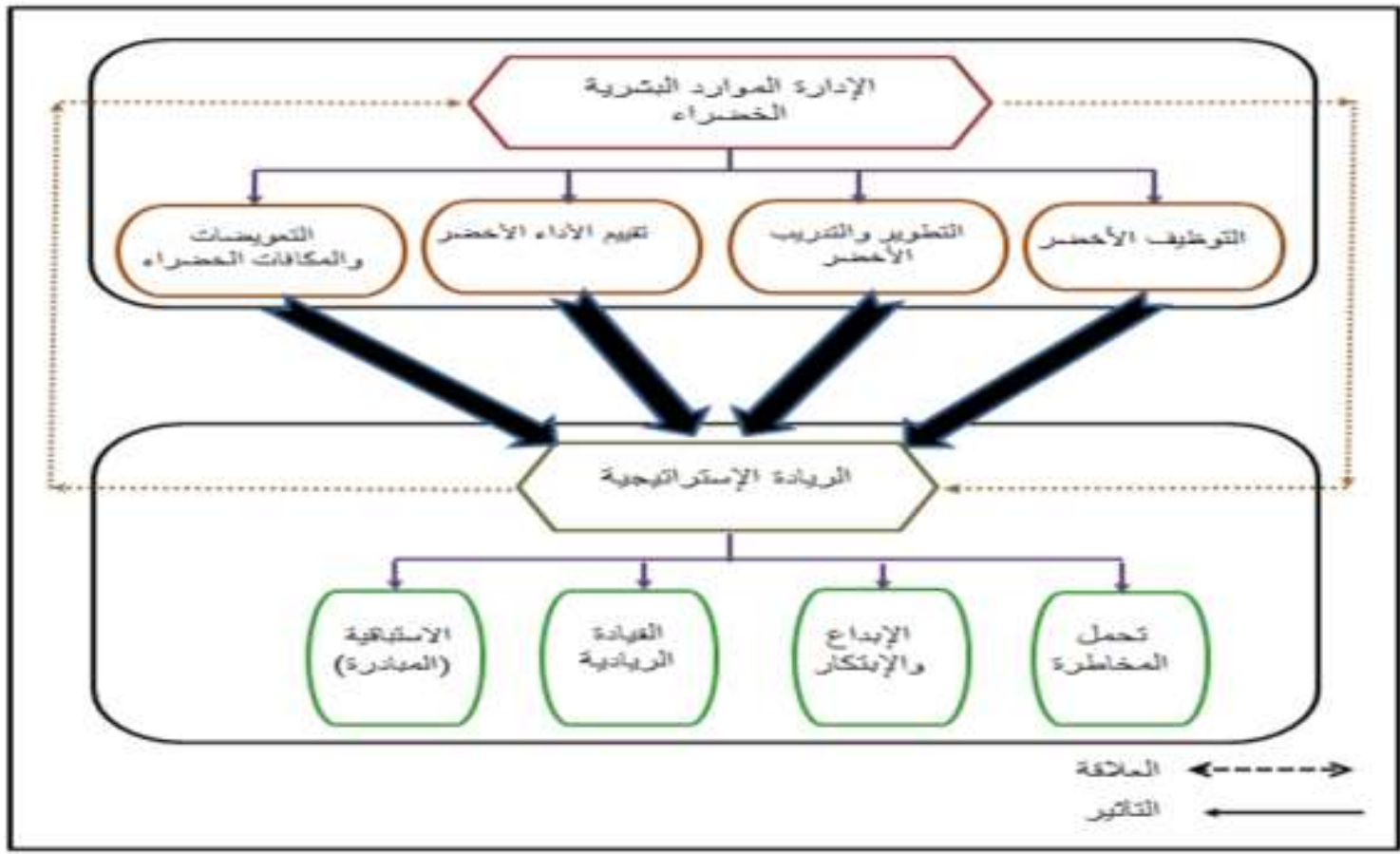

الثكل (1): المخطط الفرضي للبحث

المصدر : من إعداد الباحثنان.

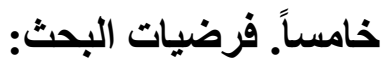
الفرضية الرئيسة الأولى: تختلف آراء المستجيبين في الجامعات المبحوثة تجاه وصف متغيرات الار اسة الحالية. الفرضية الرئيسة الثانية: تختلف الأهمية الترثيبية لأبعاد متغيري الدراسة باختلاف آراء المستجيبين.

الفرضية الرئيسة الثالثة: توجد علاقة معنوية ذات دلالة إحصائية بين ممارسات إدارة الموارد البشرية الخضر اء و الريادة الاستر اتيجية منفردة ومجتمعة التئهة الفرضية الرئيسة الرابعة: يوجد تأثير معنوي ذو دلالة إحصائية لممارسات إدارة الموارد الفية البشرية الخضر اء و الريادة الاستر اتيجية منفردة ومجتمعة. سادساً. أداة الدراسة: أن الاستبانة هي الأداة الرئيسية التي سيتم الاعتماد عليها لجمع بيانات

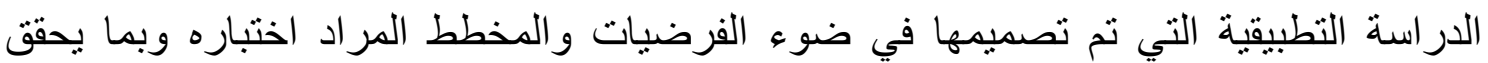
أهدافها. وتمثل الاستبانة وسيلة قياس إدر اكية للحصول على البيانات و المعلومات لأنها تلائم كثير آ

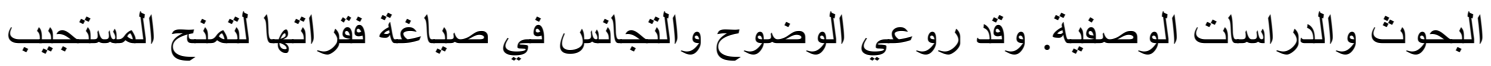

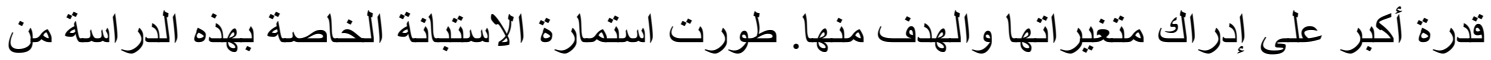

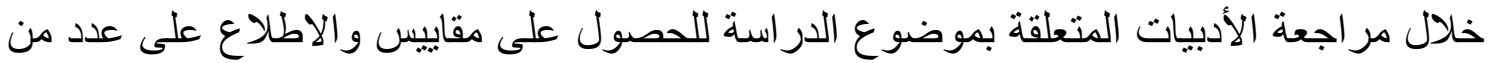

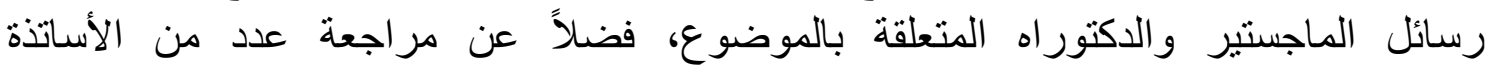

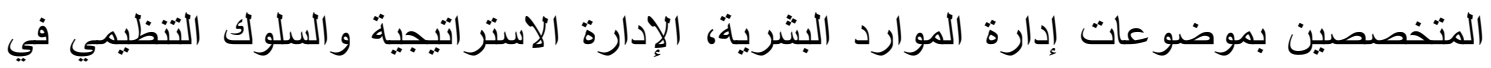

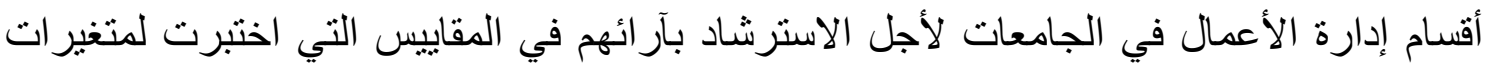
وفقر ات الدر اسة النظرية. 
وبعد إعداد الاستبانة بصيغتها الأولية راجعها الباحثان وتم تدارس فقر اتها ومقاييسها وكان لذللك الأثر الكبير في تعديل صياغة بعض الفقرات واضافة فقرات جديدة من أجل تحقيق الدقة في قياس متغيرات الدراسة، وقد أعتمد مقياس ليكرت (Lekert) الخماسي (أوافق بثدة، أو افقن،

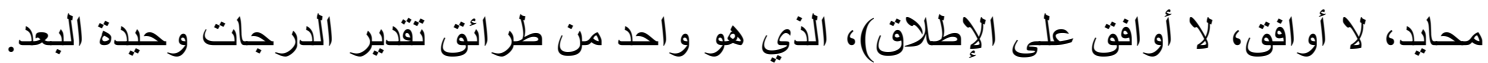

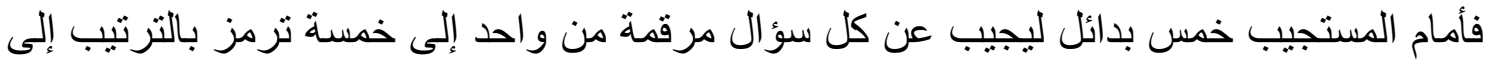

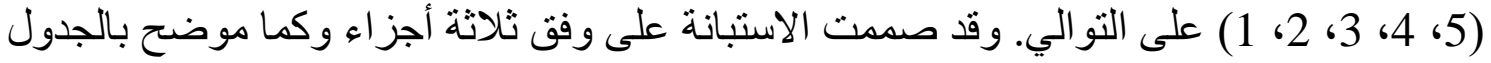
(1) فقرات الاستبانة مبوبة بحسب تسلسلها في الاستبانة. الجدول (1): متغير ات الاستبانة ومقاييسها

\begin{tabular}{|c|c|c|c|c|c|}
\hline \multirow{2}{*}{ الثقياس } & \multicolumn{2}{|c|}{ أرقام الأسئلة في الاستباتة } & \multirow{2}{*}{ المتفرات الفرعية } & \multirow{2}{*}{ العتفير الزئبسي } & \multirow{2}{*}{$\Delta$} \\
\hline & إلى & ه & & & \\
\hline من إعداد الباحثًان & 5 & 1 & 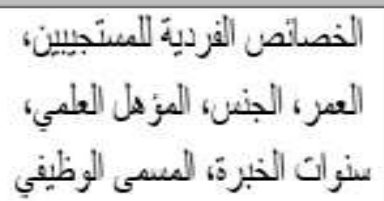 & المعلومات الثخصبة & 1 \\
\hline \multirow{4}{*}{ 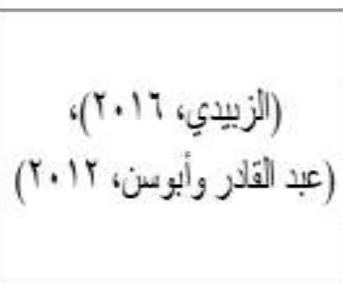 } & $\mathrm{X} 7$ & $\mathrm{Xl}$ & التُوظيف الأخضر & \multirow{4}{*}{ البشرية الخضراء إدارة المو ارد } & \multirow{4}{*}{$r$} \\
\hline & $\mathrm{X} 14$ & $\mathrm{X} 8$ & التطّير والتُريب الأخضز & & \\
\hline & $\mathrm{X} 21$ & $\mathrm{X} 15$ & قهيلي الألداء الأخضر & & \\
\hline & $\mathrm{X} 28$ & $\mathrm{X} 22$ & التعويضات والمكأفات الخضراء & & \\
\hline \multirow{4}{*}{ 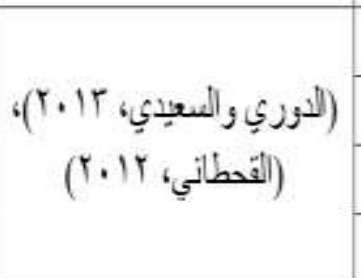 } & Y7 & Y1 & تحمل المذاطزة: & \multirow{4}{*}{ الزريادة الانسترالتيجية } & \\
\hline & Y14 & Y8 & الإبداعوالابتكار & & $r$ \\
\hline & Y21 & Y15 & القيادة الزيادية & & 1 \\
\hline & Y28 & $\mathrm{Y} 22$ & 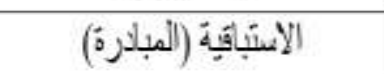 & & \\
\hline
\end{tabular}

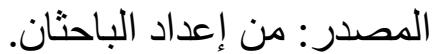

سابعاً. مجتمع البحث وعينته: يتمثل مجتمع البحث بالجامعات الخاصة في مدينة أربيل والبالغ

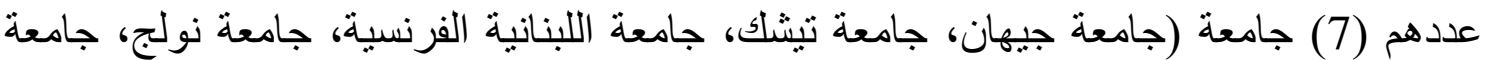

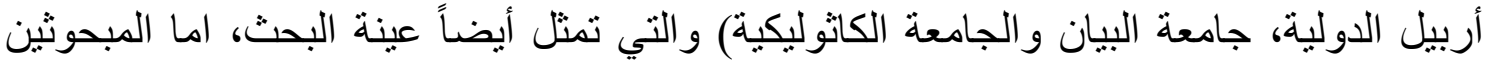

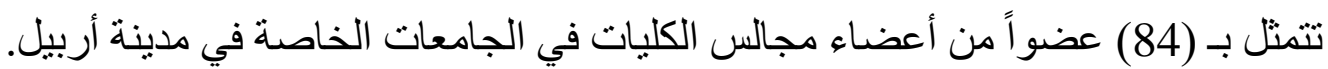

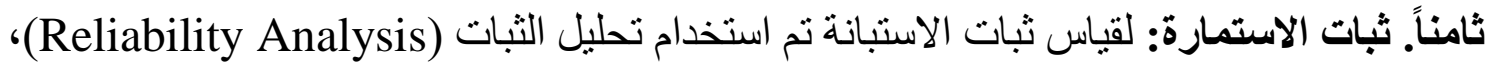

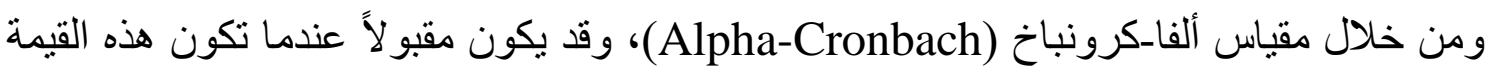
مساوية أو أكبر من (0.60)، ولغرض التأكد من دقة قياس متغيرات الاستبانة فقد قام الباحث

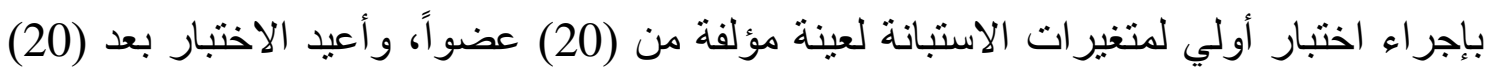

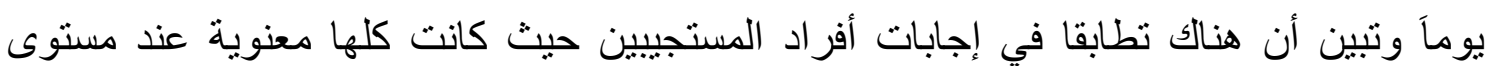
(0.05) وهذا مؤشر للثبات المرتفع لأن كل قيم أكبر من (0.60) وقد أخذت الاستبانة صيغنها

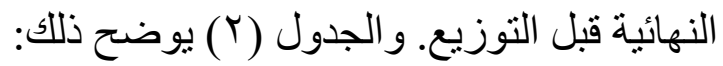


الجدول (r): اختبار ألفا كرونباخ لثبات الاستبانة

\begin{tabular}{|c|c|c|}
\hline قيمة المعامل & عدد العبارات & أبعاد ومتغيرات الدراسة \\
\hline 0.842 & 7 & التوظيف الاخضر \\
\hline 0.783 & 7 & التطوير و التدريب الاخضر \\
\hline 0.878 & 7 & تقييم الاداء الاخضر \\
\hline 0.910 & 7 & التعويضات و المكافآت الاخضر \\
\hline 0.804 & 7 & تحمل المخاطرة \\
\hline 0.901 & 7 & الابداع والابتكار \\
\hline 0.900 & 7 & القيادة الريادية \\
\hline 0.940 & 7 & الاستباقية \\
\hline 0.949 & 28 & أبعاد ممارسات ادارة الموارد البشرية \\
\hline 0.957 & 28 & أبعاد الريادة الاستر اتيجية \\
\hline 0.967 & 56 & جميع عبار ات الاستبانة \\
\hline
\end{tabular}

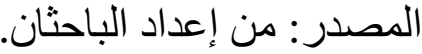

الفصل الثاني: الجانب النظري

أولاً. مفهوم إدارة الموارد البشرية الخضر اءو وأهميتها

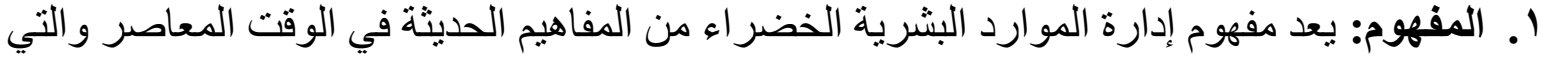

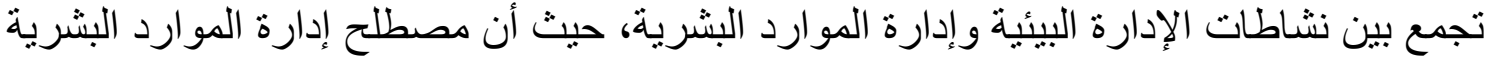

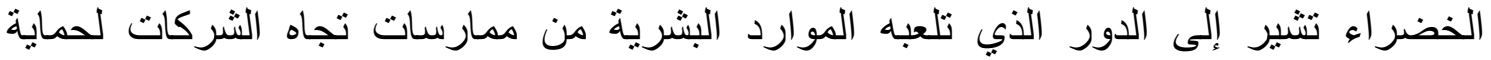

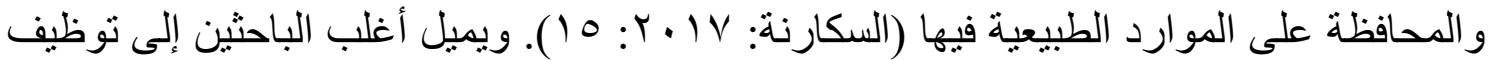

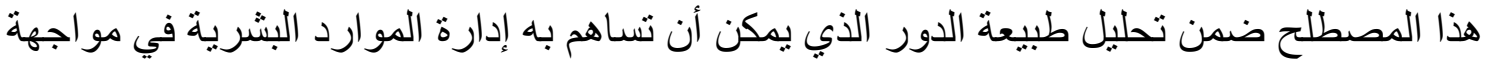
التحديات البيئية التي تفرض على المنظمات بذل الكثير من الجهد لتحسين مستوى الأداء البيئي

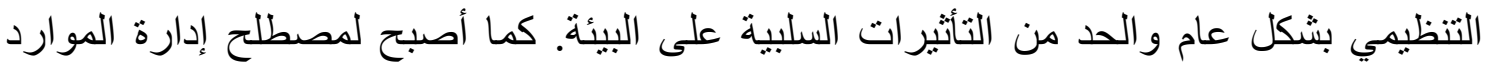

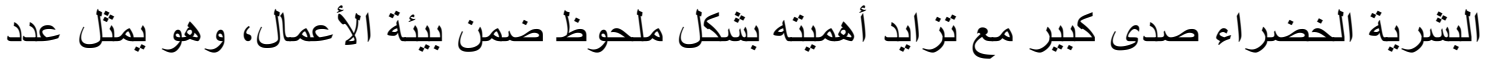

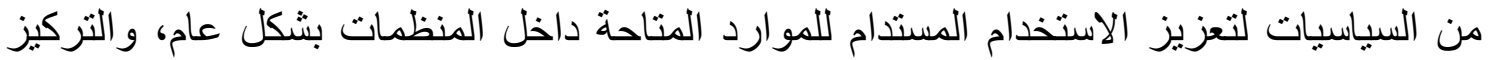
على البيئة المستدامة بشكل خاص (Mandip, 2012: 244).

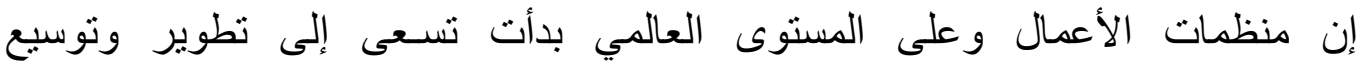
استراتيجياتها المتعلقة بادوار ووظائف الموارد البشرية بطريقة تصل إلى الاستدامة البيئية، من البنائن

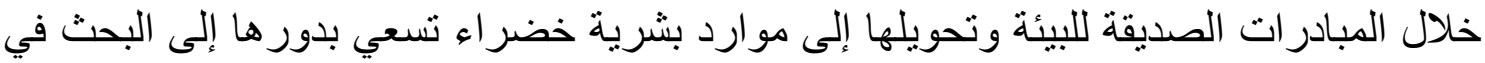

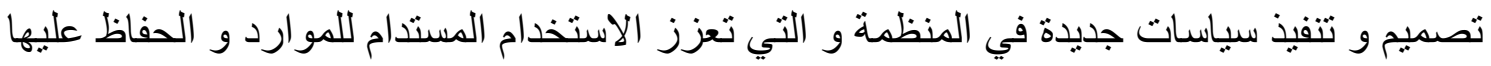

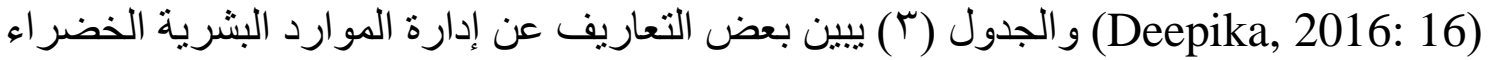
من وجهة نظر بعض الكتاب و الباحثين. 
الجدول (r): تعاريف إدارة الموارد البشرية الخضر اء

أنها كافة الوظائف التي يستوجب البه على إدارة

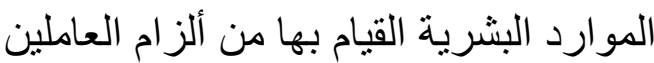

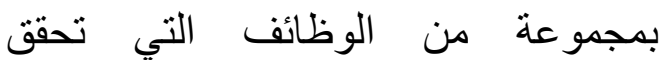

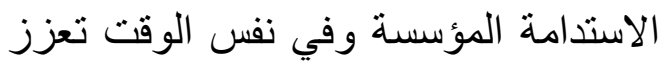

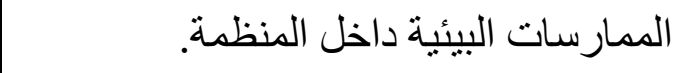
أن إدارة الموارد البشرية الخضر اء تشاهـاهم بشكل ملحوظ في إنشاء منظمات بيئية، و الى زيادة مشاركة الموظفين في عملية الابتكار ات البيئية، و الحد من النفايات البيئية وزيادة كفاءة العمليات، وتحفيض التكاليف.

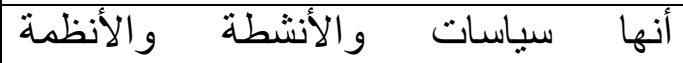
و الممارسات المتضمنة التنفيذ و الصيانة و التطوير المستمر الذي يهدف الى البحث

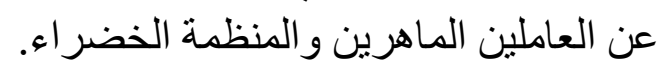

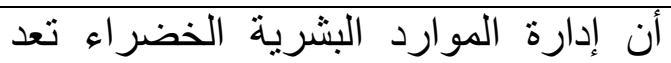

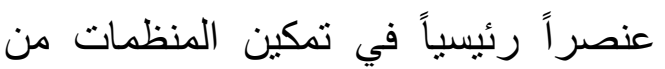

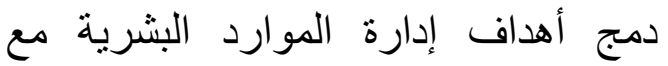

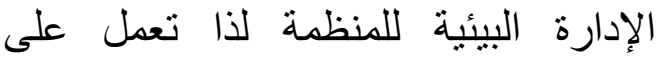
تحسين التمكين الأخضر الذي يساهم في زيادة المشاركة الموظفين في إدارة مجالات أنها توظيف سياسات إدارة المو ارد البشرية في تشجيع الاستخدام الأمثل للموارد داخل إنل

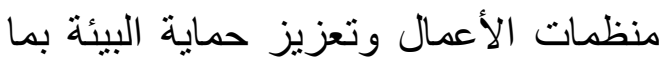
ساهم في الرفع من رضات ومعنويات الموظفين. تمثل المو اعمة بين ممارسات ادارة الموارد البشرية والاهتمام البيئي ويمثل نماعل نشاطاً منهجياً ومخططاً تهدف الى تتفيذ الأفكار و الممارسات المبتكرة للحفاظ على الموارد البشرية الكفو عة وحماية البيئة.

Kanika Sharma، 2016: 8-9

Norton, et al., 2017: 996

Mishra, 2017: 775

Peerzadah, Mufti \& Nazir, 2018: 790

Nejati et al., 2017: 165

Milad Malko Nuh, 2020: 5

المصدر : من إعداد الباحثان.

ץ. اهمية إدارة الموارد البشرية الخضراءئ تساهم إدارة الموارد البشرية الخضر الثراء في تحسين بيئة

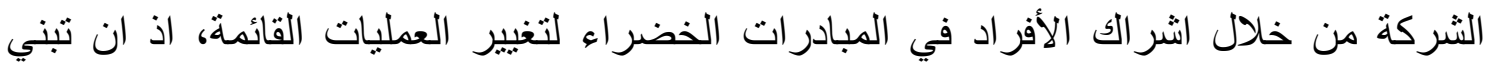

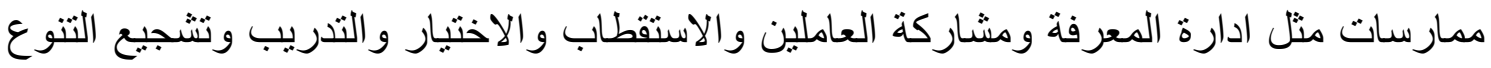




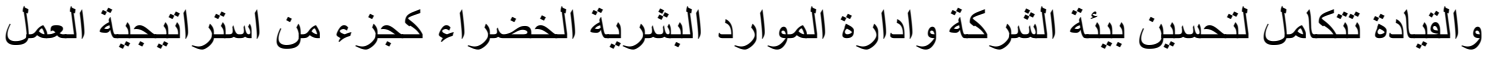

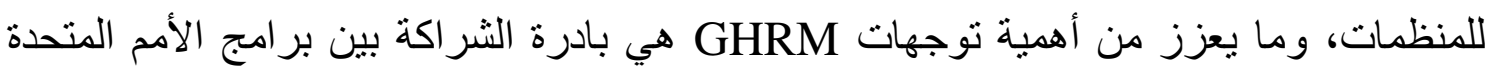

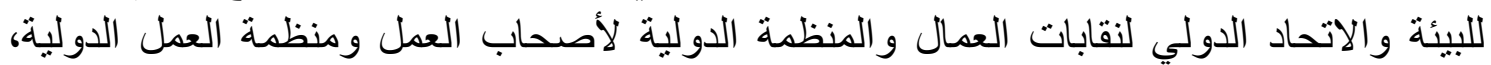

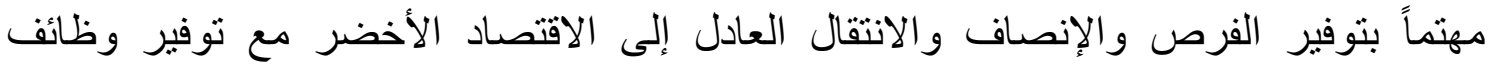

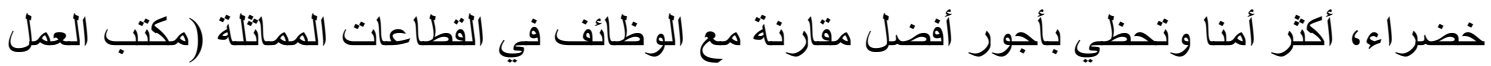

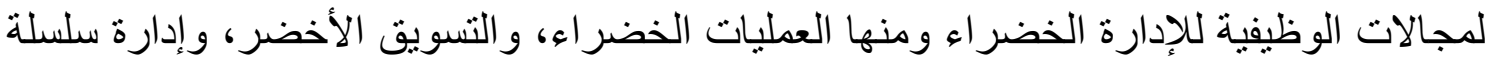

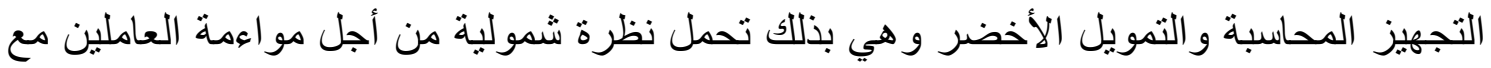

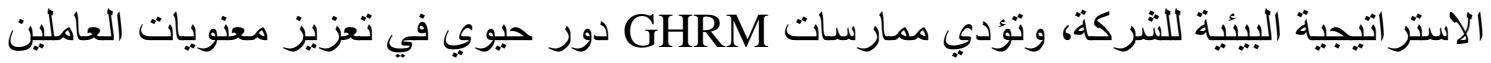

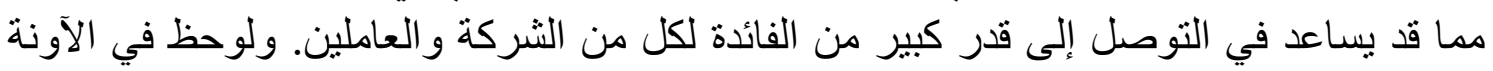

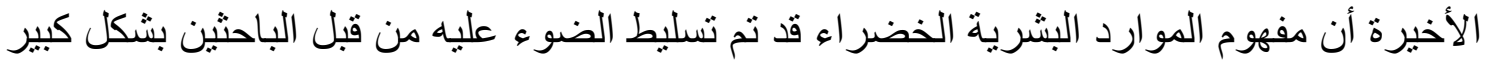

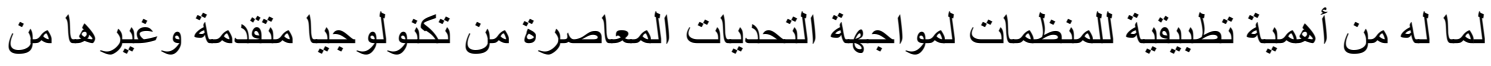

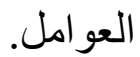

لذا أكد (Nijhawan, 2014) إن هناك حاجة متز ايدة للاندماج ما بين الاستدامة

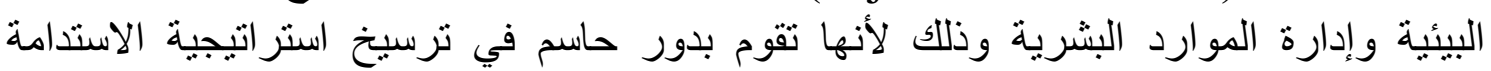

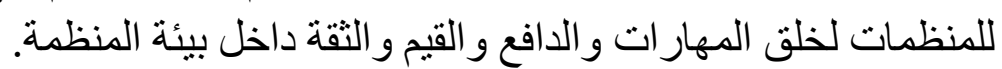

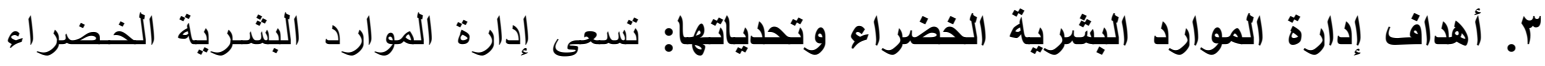
تحقيق مجموعـة مـن الأهداف وعلى الزئل النحو الآتي: (Cherian\&Jacob, 2012: 21)

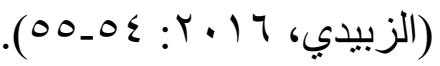
ـ تحسين معدلات الاحتفاظ بالعاملين. ـ تحسين صورة الثركة لدى الجمهور وتلبية احتياجات الزبائن. ـ ت تحسين عملية جذب أفضل الموظفين. ـ ـ تحسين الإنتاجية و الاستدامة.

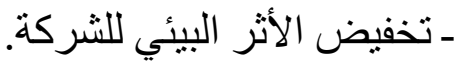
ـ تحسين القدرة التنافسية وزيادة الأداء العام. ـ ـ تحقيق عو ائد مستدامة للمستثمرين. ـ ـ الاستجابة للاتجاهات المجتمعية الطارئة. ـ الاستجابة للتوقعات الحكومية و التنظيمية. ؛. ابعاد ممارسات إدارة الموارد البشرية الخضراءة: الباءية جاءت ممارسات الإدارة الموارد البشرية

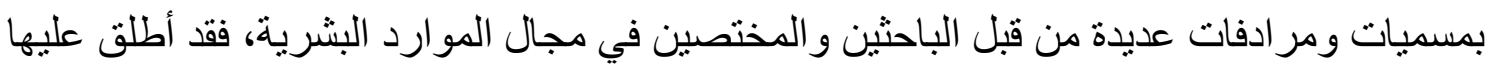

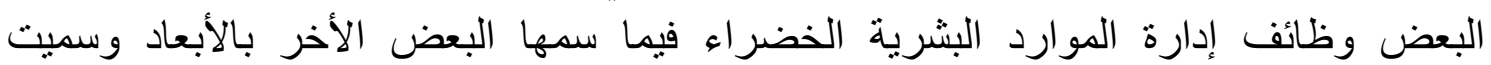

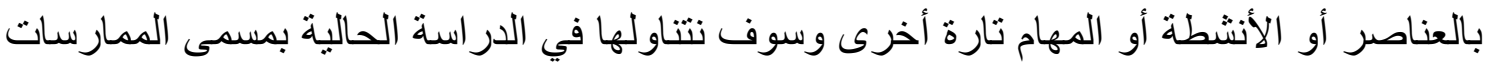

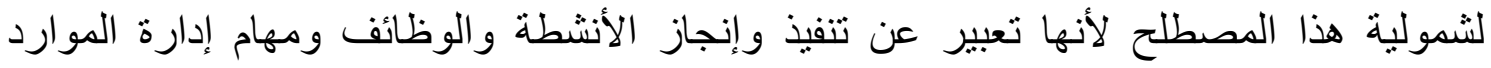

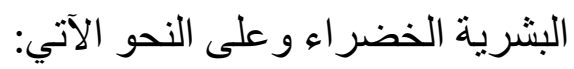

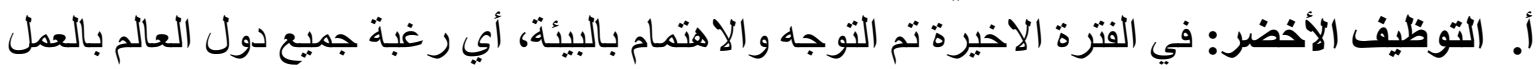

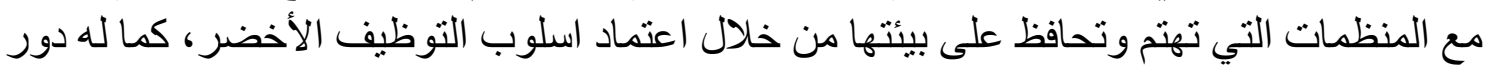

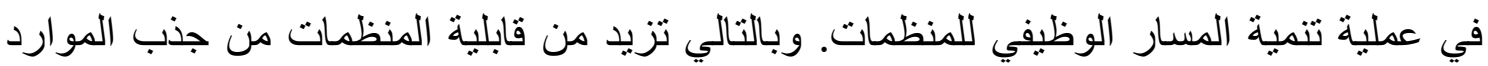


البشرية، لان التوظيف الجيد يعتبر أحد اهم المزايا التنافسية من الموارد البشرية، حيث كلما كانت

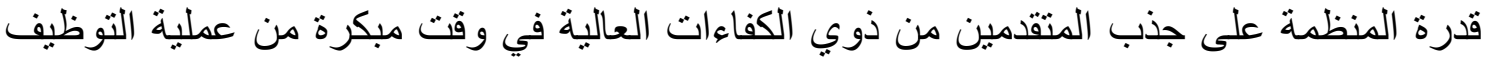
كلما كان لها تأثير على المراحل اللاحقة للمنظمة وبالتالي تحقيق أهداف دوب على المدى الطويل (Baum et al., 2016: 7) يمكن المنظمات من الاستدامة و الحفاظ على البيئة من خلال جذب المستقطبين الماهرين، وبالتالي

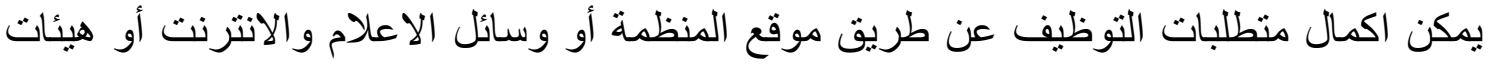

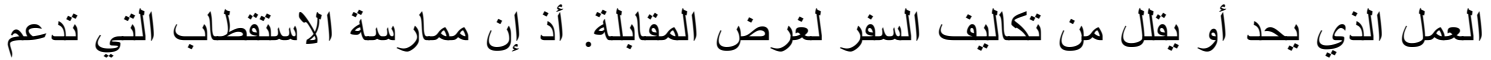

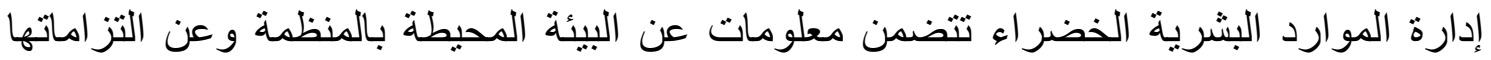

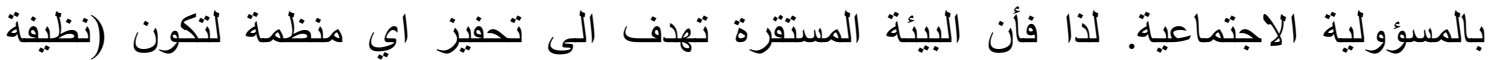
وخضر اء) وتعمل على تشجيع تللك المنظمات لتحسين أداءها.

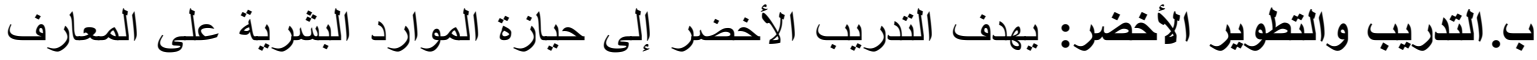
و المهار ات و الاتجاهات المؤثرة في سلوكهم الأخضر، و وذا ما يفرض الأبر على إدارة الموارد البشرية الخضر اء توفير التدريب و التطوير للقياديين والموظفين في المجال البيئي بهدف تنمية الوعي البيئي

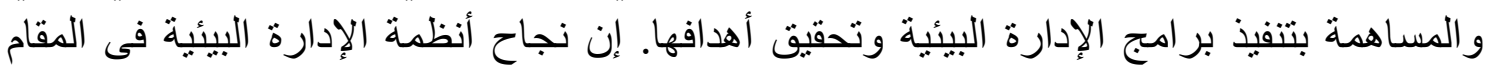

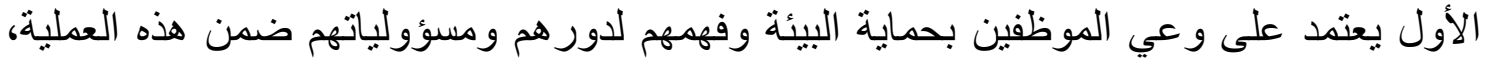

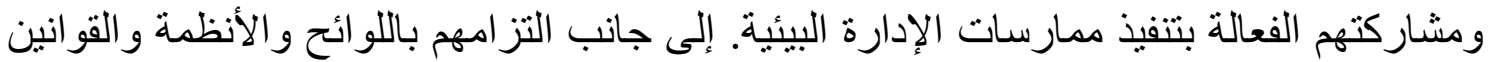
البيئية، وهو الأمر الذي يتعين أن يتحقق من خلال تدريبهم على تلاك الممارسات وتطوير قدر اتهم، خاصة من خلال برامج التدريب الأخضر لما لها من دور فاعل فئ في تنمية مهار الات الموظفين الداعمة للممارسات البيئية الفعالة. ضمن هذا السياق يؤكد (Arulrajah \& al., 2015) على لئى أهمية توفير التدريب البيئي للموظفين و القياديين، بغية تطوير مهار اتهم ومعرفتهم بالممارسات

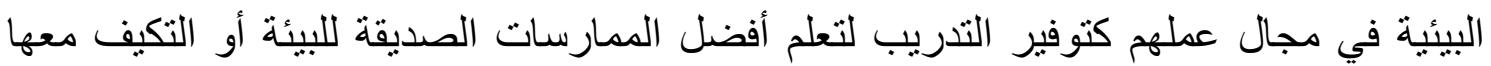
(على سبيل المثال: إعادة التدوير وتطبيق الوظيفي كأداة للتطوير القيادي المستقبلي لمديري البيئة

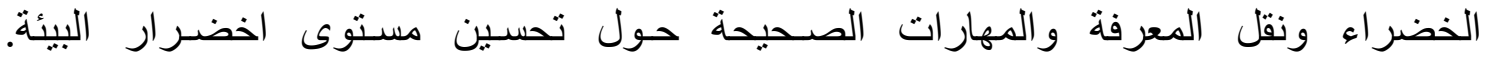
(Arulrajah \& al., 2015: 5)

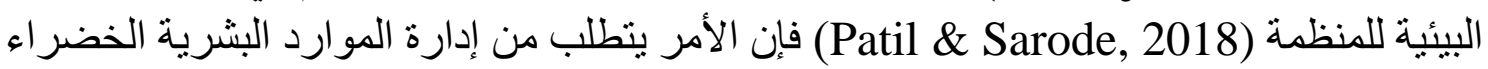
أن تقوم بتقدير الاحتياجات التدريبية في المجال البيئي بجمع المعلومات عن البيئة التنظيمية

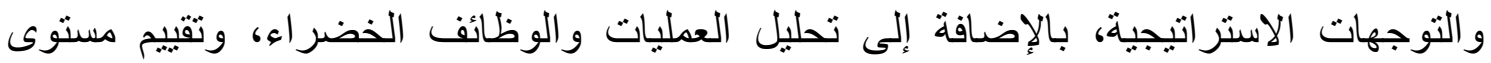

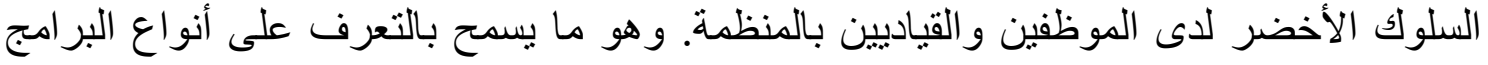
التدريبية وتحديد قائمة الموظفين الذين هم بحاجة إلى تلك البرامج المساعد على إحداث التغيير

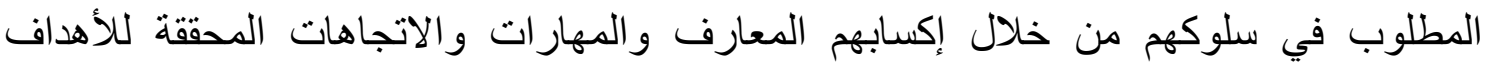
الخضر اء، علاوة على وضع أهداف دقيقة واضحة ومواد تعليمية حديثة وفق أساليب متو افقة مع مبادئ التعلم، وكذلك قيام تللك الإدارة بتقييم مدى فاعلية بر امج التدريب الأخضر باستخدام أدوا ت

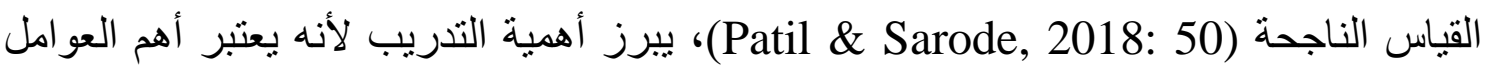

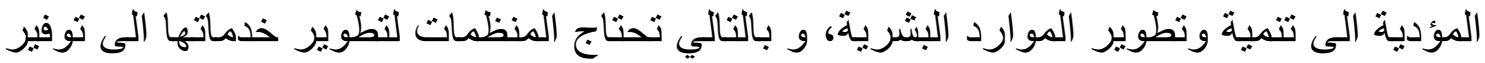
التدريب الاخضر الذي ينص على تطوير العاملين واستخدام تكنولوجية متطورة و أكثر كفاءة من حيث استغلال الموارد الطبيعية (Neto et al., 2014:388). 
ج. تقييم الأداء الأخضر: تعرف إدارة الأداء بشكل عام على أنها العملية التي يتم من خلالها حث

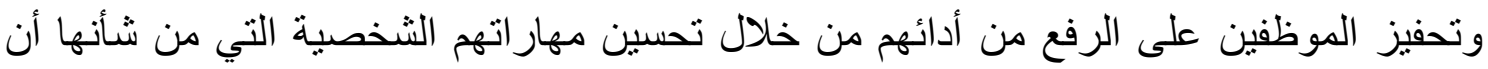

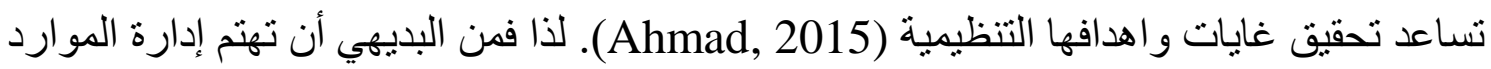

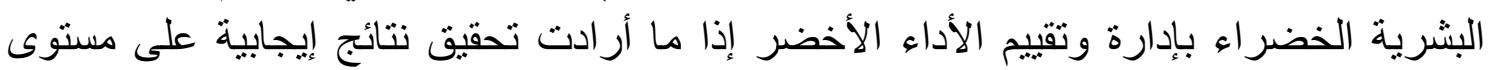

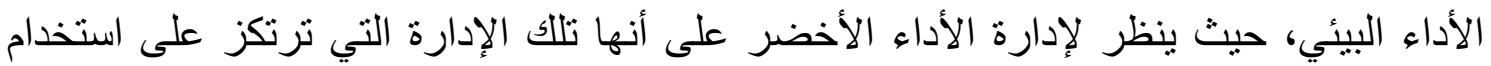

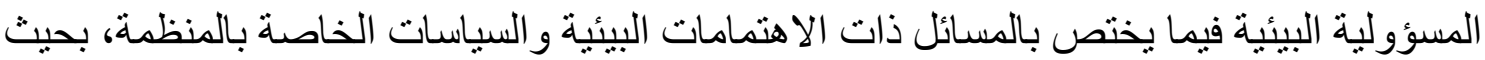

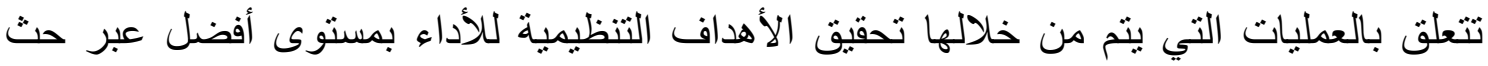

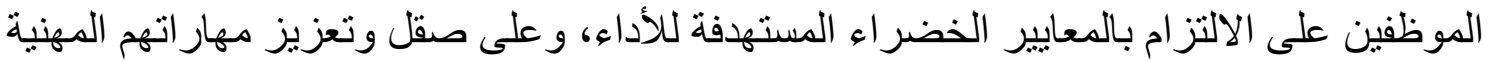
المحققة لذلك، بما في ذلك قياس الأداء الأخضر ـ و هكذا و لأجل تحقيق الأداء البيئي الجيد و استدامته، فإنه يتعين على المنظمات أن تحوز من جهة، على نظام معلومات للإدارة البيئية يتم من خلاله تحقيق المتطلبات البيئية عبر رصد الجوانب ذات العلاقة كالتلوث و إدارة النفايات واستخدام الطاقة و الموارد بشكل عام، ومن جهة أخرى فإن هذا النظام يجب أن يكون مصحوبا بعمليات للتدقيق

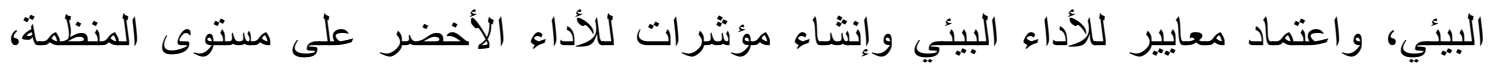

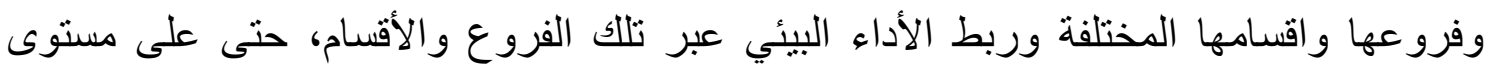
الأفر اد بالأداء العام للمنظمة (Ahmad, 2015:23).

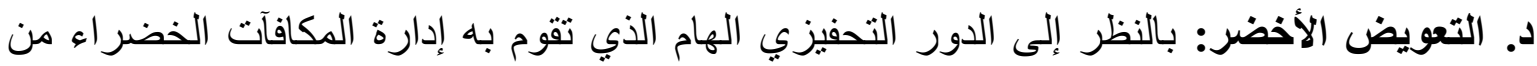

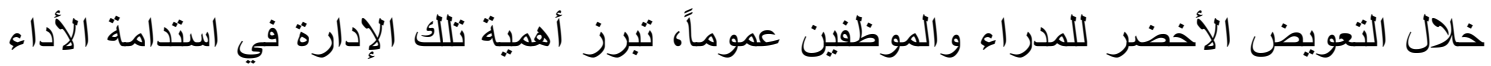

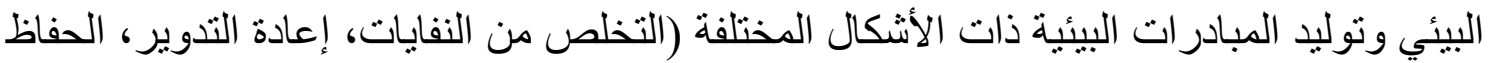

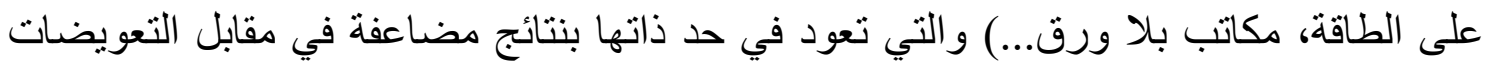

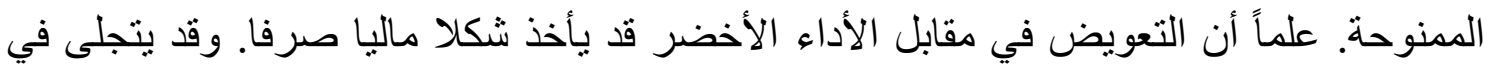

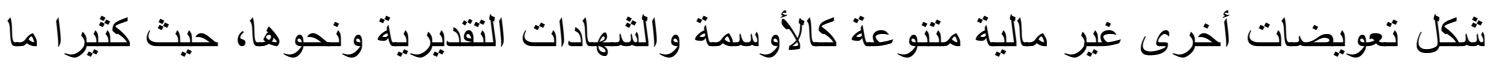
يلجاً لهذا النوع الأخير (غير المالي) في ظل ندرة المكافآت المالية لدى المنظمات. إن دمج عناصر

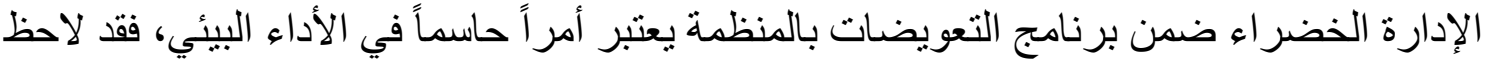
(Forman \& Jorgensen, 2001) للموظف، كما وجدت در اسة (Berrone \& Gomez-Mejia, 2009) التي أجريت على (469) شركة امريكية تعمل في صناعات عالية التلوث أن الثـركات التي لديها أداء صـديق للبيئة دفعت لمديريها التنفيذيين تعويضـات أكثر مدـا دفعـت الثـركات غيـر الصـديقة للبيئة.

(Berrone \& Gomez-Mejia, 2009: 52) ثنانياً. الريادة الاستراتيجية:

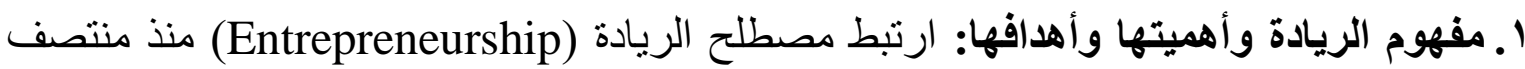

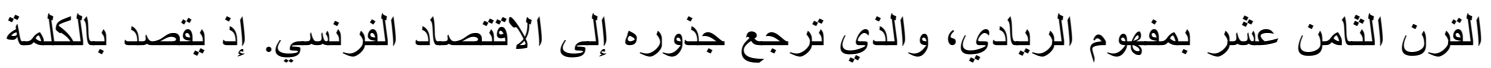

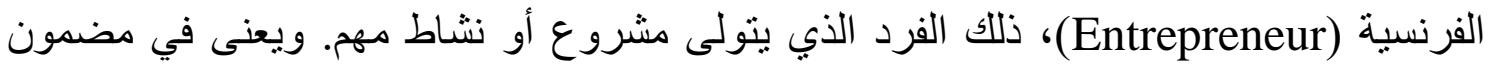
الأعمال بمصطلح (Undertake) هو بدء الأعمال. وفي قاموس (Webster) يمثل منئ الريادي ذللك الفرد الذي ينظم ويديـر ويتحمل مخـاطر الأعمـال أو المشـروع. (Entrepreneur)

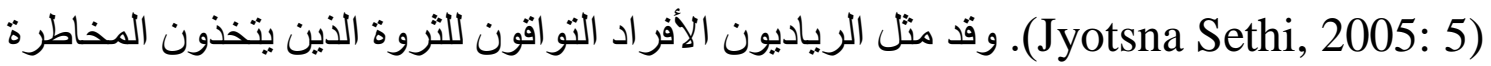
ويصنعون القرار لإدارة الموارد بطرائق غير مألوفة لاستثمار الفرص وبذللك أصبحوا قادة التاد 
الصناعة في العالم. (QuickMBA, 2007: 55). فيما أنشار (Robert Hisrich, 2002:

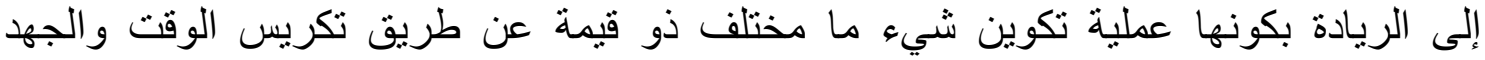

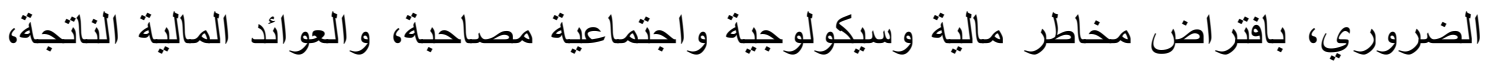

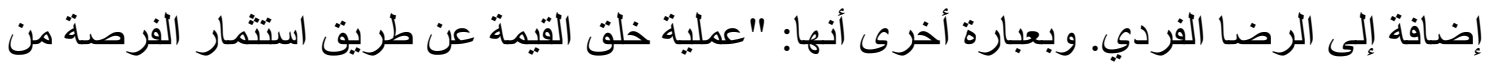

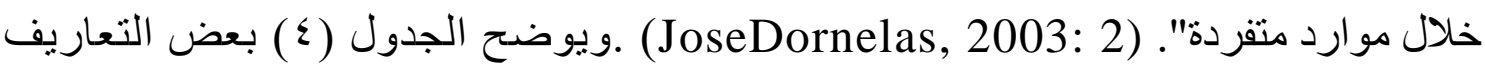

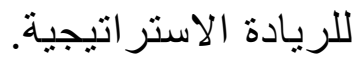
الجدول (๕): تعاريف الريادة الاستر اتيجية

\begin{tabular}{|c|c|}
\hline 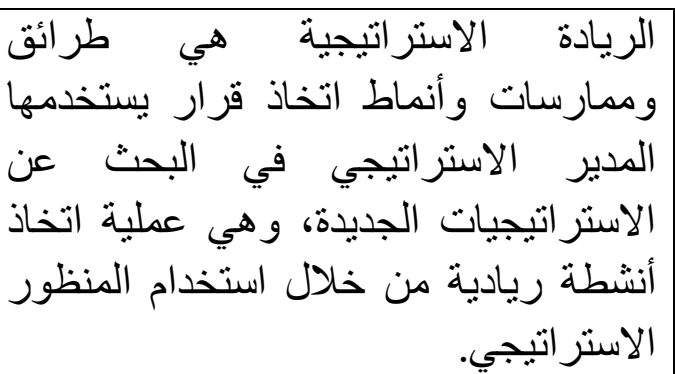 & 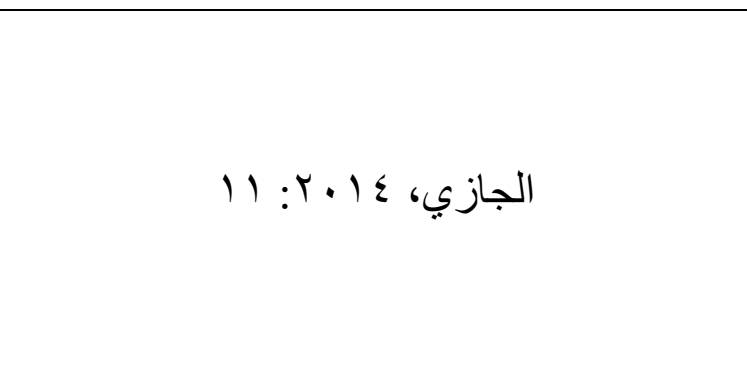 \\
\hline 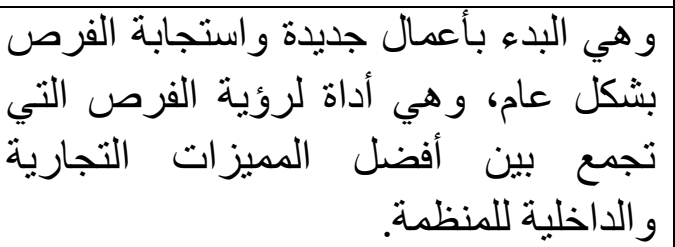 & Robbins, Decenzo \& Coulter, 2015: 471 \\
\hline 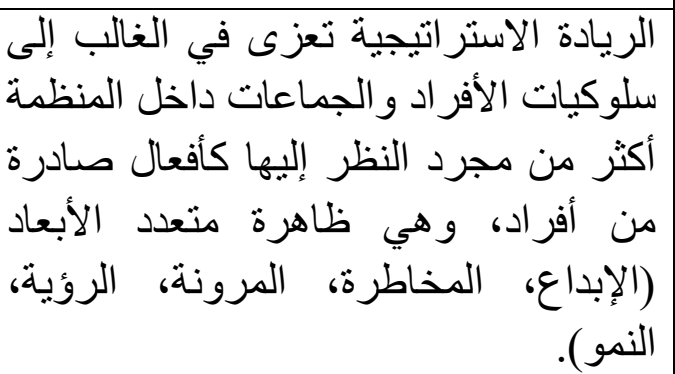 & الغالبي و آخرون، 7 ( • ץ: • 19 \\
\hline 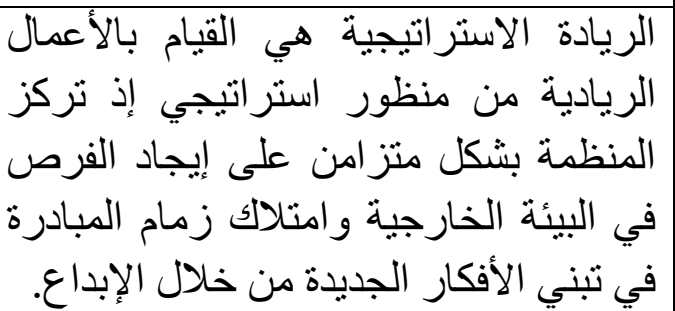 & الحكيم و علي، V • • Y: 0 \\
\hline 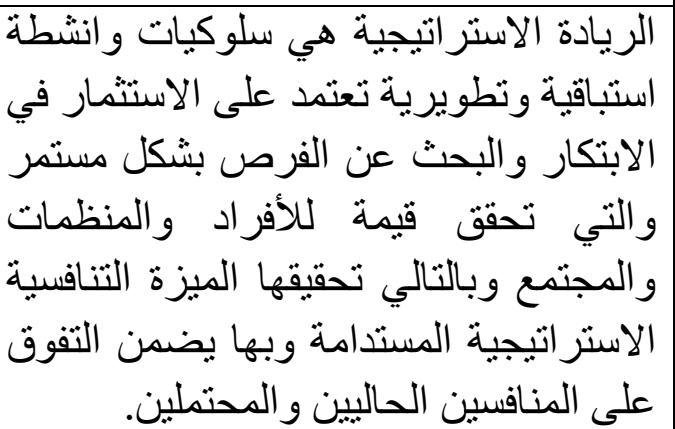 & Kuratko \& Morris, 2018: 45 \\
\hline
\end{tabular}

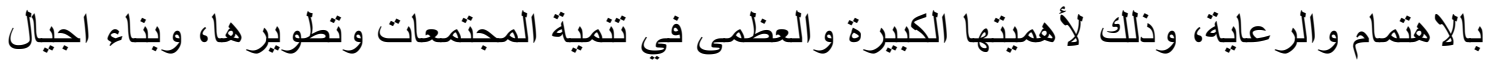


قادرة على خلق الفرص و اقتناصها، وقادرون على تبنيها، ويمتلكون القدرة على الابتكار ، والإبداع،

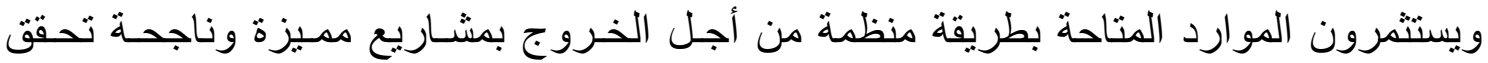

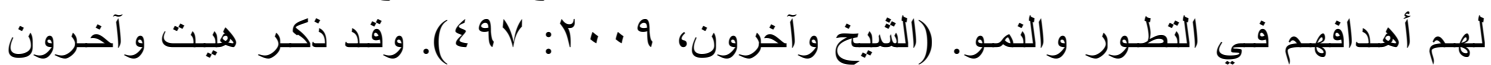
(Hitt et al., 2011: 68) وتوفير وظائف جديدة، وبالإمكان أن تقدم فوائد أخرى للمجتمع.

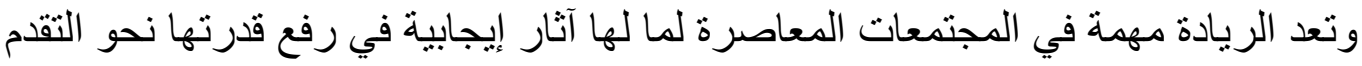

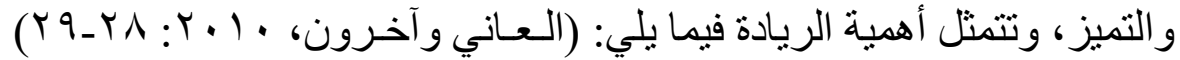

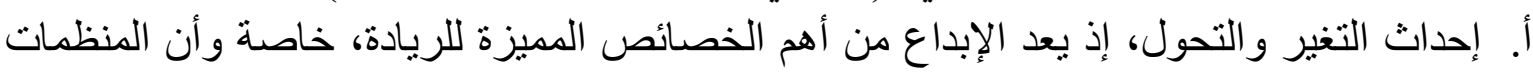
الريادية تعمل كوكيل للتغيير من خلال ممارسة الأنشطة الريادية.

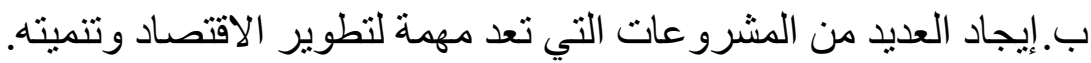

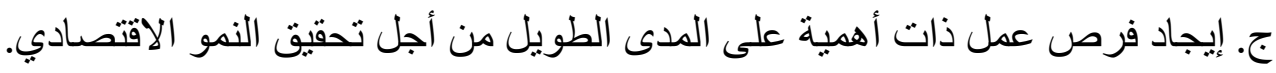
د. زيادة الكفاءة من خلال زيادة التنافس، اذ أن دخول منافسين جدد يحفز الآخرين للاستجابة بشكل كفؤ وفعال.

ه. إحداث التغير في هيكل السوق و العمل من خلال تبني الإبداع التنظيمي و التكنولوجيا الحديثة. و. احتمالية إدخال ابتكار جذري يترك أثنار إيجابياً في الاقتصاد بشكل فئس كامل للمنظمة.

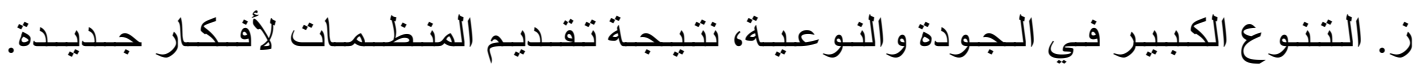

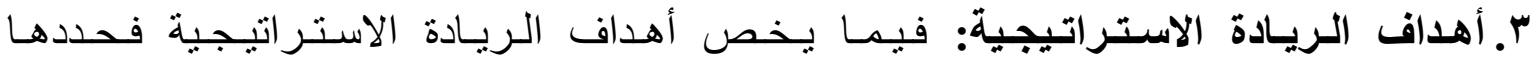

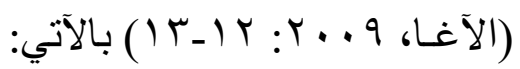
ـ تحديد أولويات طويلة الأجل للمنظمة في ضوء الاتهي: الرسالة الحالية و التغير ات و التحو لات في الظروف البيئية المحيطة ومع تطور المنظمة في مر احلها المختلفة. ـ إعطاء توجه عام يتم في إطاره وضع الأهداف أكثر تحديداً وتفصيلاً للمستويات الأدنى و الوحدات

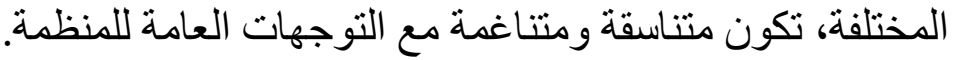
ـ المساعدة في تحديد الأنشطة الرئيسية و الفرعية للمنظمة و الأعمال التي بلزمة القية القيام بها في مجالات الأنشطة المختلفة بما يمكن من تحقيق الأهداف ذات الأولوية في الفتر ات الزمنية الزية الممتدة.

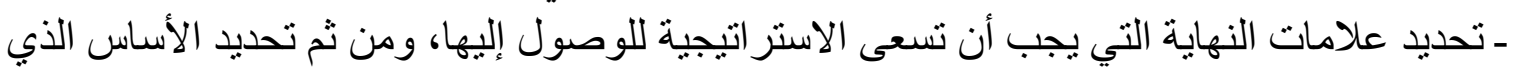

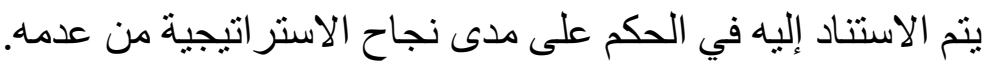
ـ تسهيل الرفاهية الإدارية من خلال المعايير المشتقة من الأهداف التي تستخدم في تقييم ادئه اداء المنظمة.

\section{ع. أبعاد الريادة الاستراتيجية:}

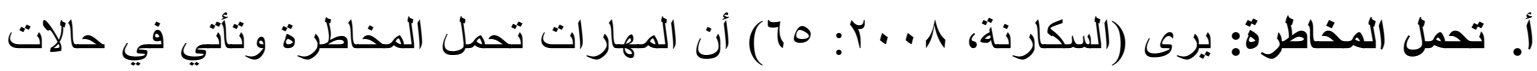
الغموض و عدم التأكد والكيفية التي تضمن بقاء وضمان نجاح الأعمال و الخوف من الفشل، حتى يقى الفرد ريادياً لابد من أن تحسب المخاطر التي تأتي من القيام بتنفيذ الأعمال وتساعد العناصر الآتية في تنكيل مهار ات لمو اجهة المخاطر و التعامل معها:

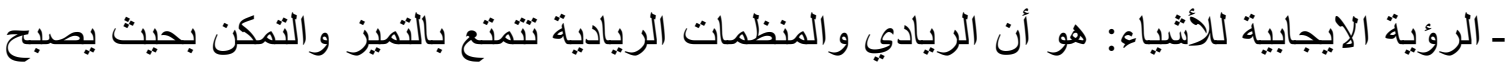

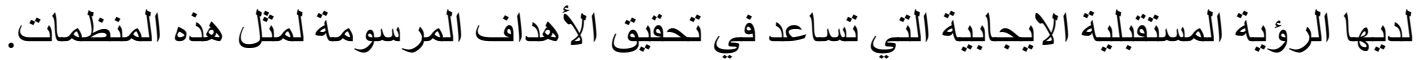

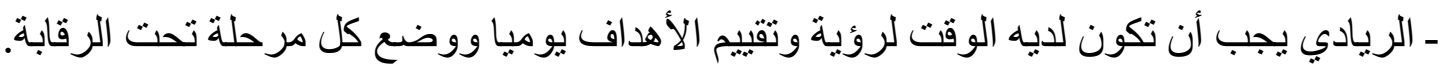


ـ العمل على تقييم الأعمال بعد انجاز كل مهمة، و على العكس في حالة عدم الانجاز والمقارنة بين ذلك.

ب.الإبداع والابتكار: يمثل الإبداع إنتاج وتطبيق ابتكاري لأفكار جديدة تؤدي إلى تحسين المنتجات و الخدمات المقدمة للزبائن، ويشمل الإبداع مجموعة من الخطوات الإبنات التي تشمل تطبيق أفكار خلاقة

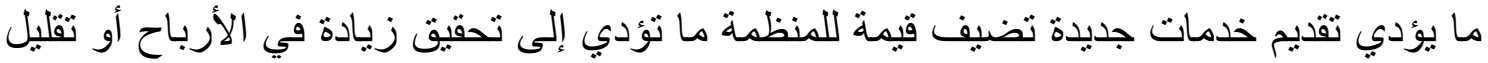

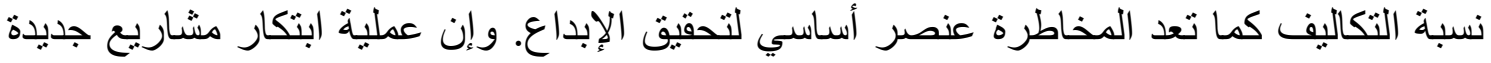
و القدرة على تأسيس تلك المشاريع في الأسواق بو اسطة استخدام فعال للموارد، أو هي عملية إنثاء شيء جديد ذي قيمة، وتخصيص الوقت و الجهر والمال، وتقبل المخاطرة المختلفة، و واستقبال

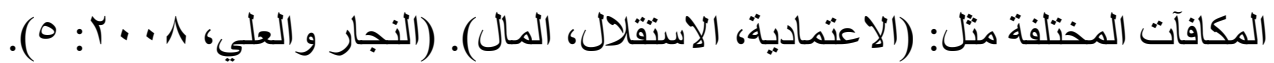
القيادة الريادية: يرى (AL-Khalifah, 2014: 1) القادة الريادية بأنها: عملية تطوير الأفكار

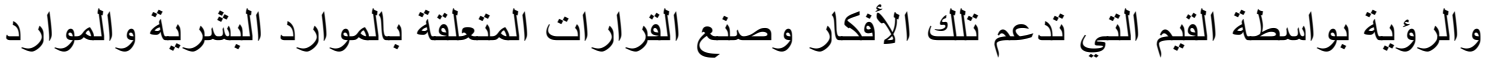
الأخرى غالبا ما تكون صعبة بهدف تحفيز الأفر اد داخل المنظمة، و القيم و المعتقدات للقائد وتوفير

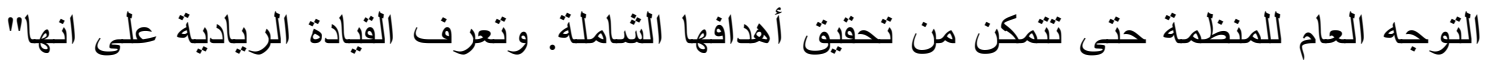
القدرة الريادي على توقع وتصور الاحداث و التفكير بشكل استراتيجي مرن للتعامل مع التغيرات البيئية وتعاون مع افر اد المنظمة لإيجاد تغييرات ت تصنع مستقبل واعد واعد للمنظمة. فالريادة تحتاج

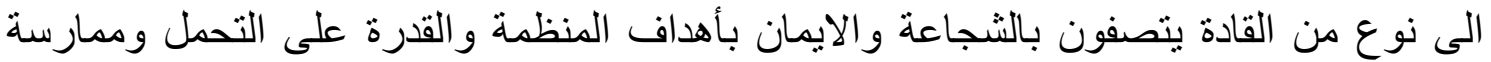

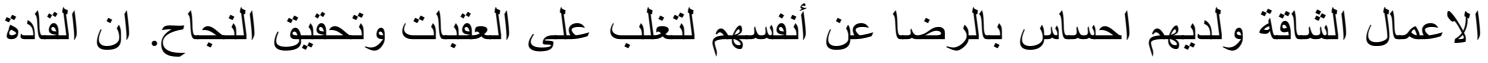
الرياديين يتصفون بخصائص وصفات تؤثر في صياغة وتوجيه الاستراتيجية الثاملة للمنظمة،

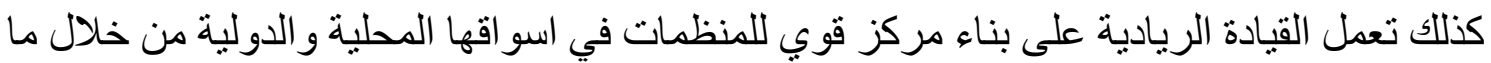

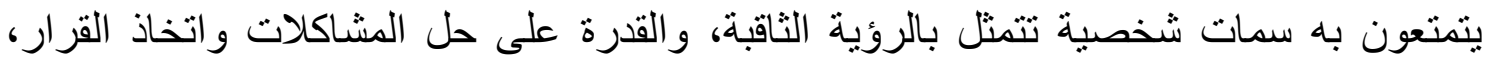
وتبني المخاطرة (11: 11: Kuratko, 2007)، (Dees et al., 2007:489).

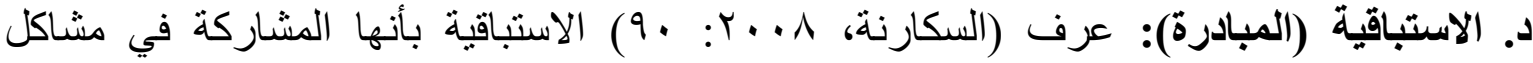

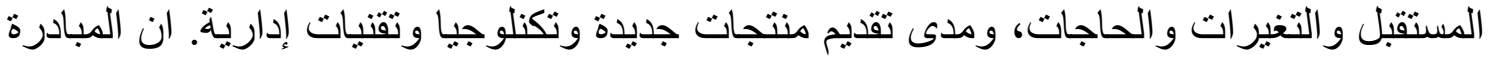
تشكل عنصر مهم وفعال للمنظمة فهي تعبر عن تشكيل شيء ذي قيمة في من لا شيء تشيء تقريباً حيث تبدأ

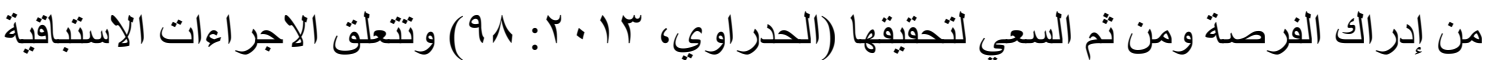

بالمستقبل و التخطيط له وتوقع التغيير ات المستقبلية.

\section{الفصل الثالث: الجانب الميداني}

المبحث الأول: وصف مجتمع البحث وعينته

تمثل مجتمع البحث بكافة أعضاء مجالس الكليات في سبعة جامعات خاصة وبلة وبلغ عددهم (172) عضواً، تم اختيار (91) عضواً منهم كعينة للبحث وتم توزيع استمار ات الاستبيان عليهم

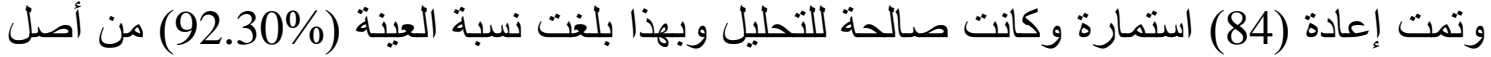
المجتمع، و هذه النسبة كافية في العلوم الإنسانية و السلوكية. وصف خصائص الأفراد المستجيبين: نستعرض في هذه فئه الفقرة الخصائص الشخصية للمستجيبين

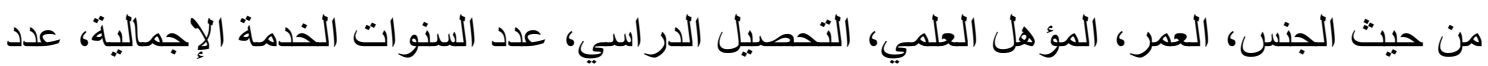
سنوات الخدمة كعضو في مجلس الكلية، و على النحو الآتي: 
ا ـ توزيع الأفراد المستجيبين على وفق الجنس: يشير الجدول (0) إلى أن نسبة الذكور في الجامعات

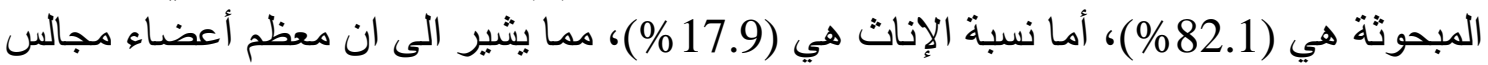

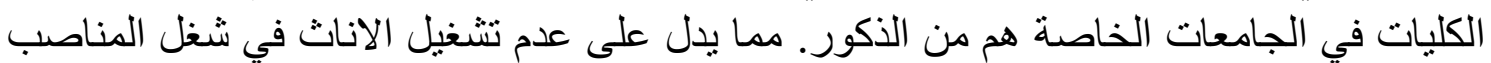

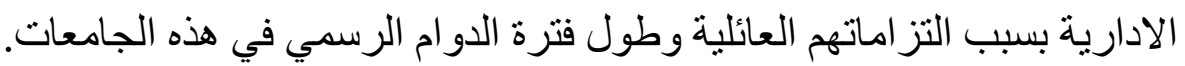

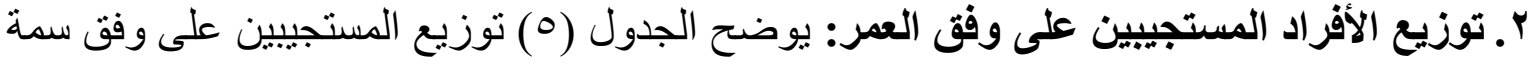

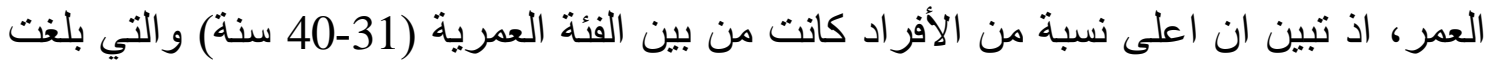

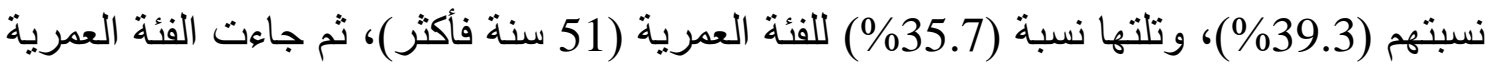
(50-41 سنة) بالمرتبة الثالثة بالنسبة (21.4\%) (23\%)، وجاءت بالمرنبة الاخيرة الفئة العمرية (30 سنة فأقل) وبنسبة بلغت (3.6\%). مما يدل على أن غالبية المستجيبين في الجامعات المبحوثة هم من القئة العمرية الناضجة و التي لا زالت تمنلك القدر ات الذهنية و الجسمانية المؤهلة للعمل وبمستويات عالية. r. توزيع الأفراد المستجيبين على وفق المؤهل العلمي: يتبين من المعلومات في الجدول (0) ان

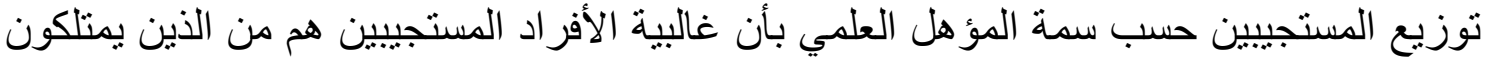

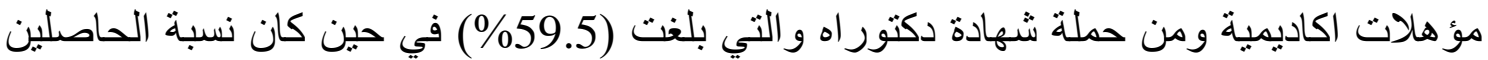

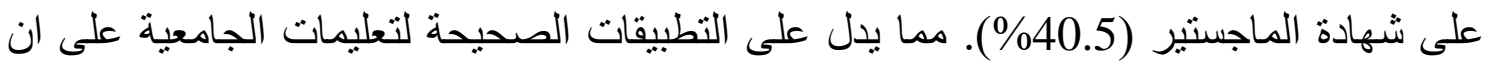
يحمل اعضاء مجالس الكليات الثهادات العالية من الدكتور اهـاه و الماجستير.

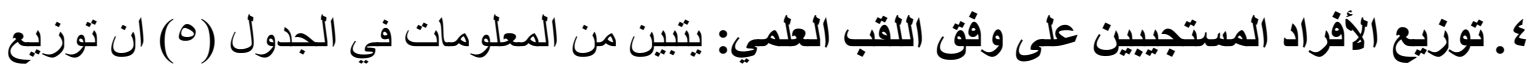
الأفر اد المستجيبين حسب سمة اللقب العلمي بأن غالبية الأفراد المستجيبين هم من الأبين الذين يمتلكون

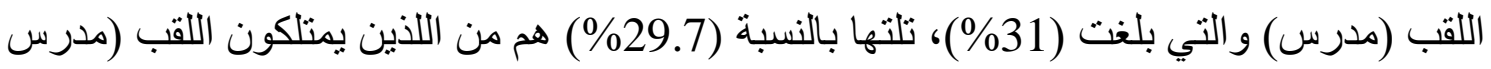

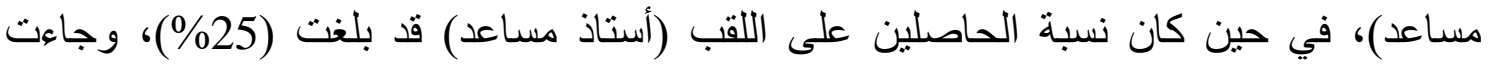
بالمرتبة الأخيرة حاملي اللقب (أستاذ) اذ بلغت (14.3\%). مما يشير الى ان أكثرية أعضاء مجالس

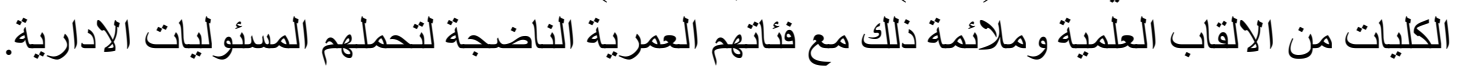

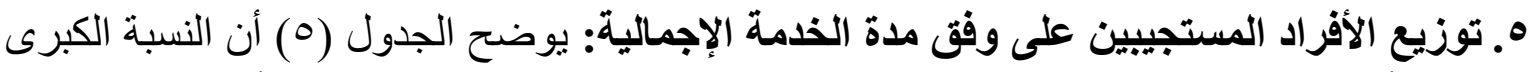
من الأفر اد المستجيبين لايهم خدمة إجمالية في العمل الوظيفي تقع بين (10 سنة فئة فأقل) و التي شكلت

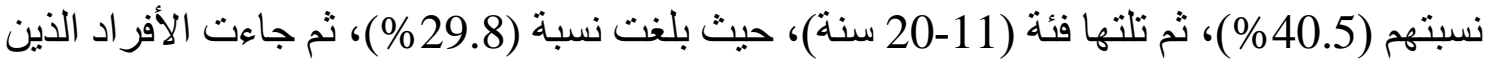

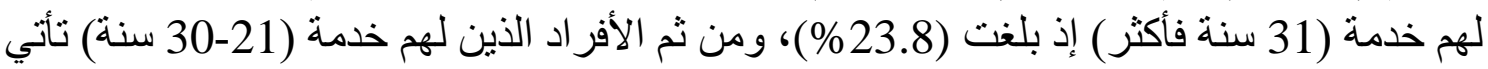
بالمرتبة الأخيرة، حيث بلغت (66). مما يدل على تر اكم الخبرات الوظيفية لدى أكثرية أعضاء

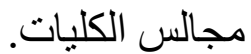

الجدول (0): وصف الخصائص الشخصية للمستجييين

\begin{tabular}{|c|c|c|c|c|c|}
\hline \multicolumn{5}{|c|}{ توزيع الأفراد المستبيبين } & العوامل \\
\hline المجموع & \multicolumn{2}{|c|}{ أنثى } & \multicolumn{2}{|c|}{ ذكر } & \\
\hline 84 & \multicolumn{2}{|c|}{15} & \multicolumn{2}{|c|}{69} & الجنس \\
\hline$\% 100$ & \multicolumn{2}{|c|}{$\% 17.9$} & \multicolumn{2}{|c|}{$\% 82.1$} & \\
\hline المجموع & \multicolumn{2}{|c|}{ أنثى } & \multicolumn{2}{|c|}{ ذكر } & العوامل \\
\hline المجموع & 51 سنة فأكثر & & 40-31 سنة & 30 سنة فأقل & \\
\hline 84 & 30 & 18 & 33 & 3 & 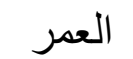 \\
\hline$\% 100$ & $\% 35.7$ & $\% 21.4$ & $\% 39.3$ & $\% 3.6$ & \\
\hline
\end{tabular}




\begin{tabular}{|c|c|c|c|c|c|}
\hline المجموع & \multicolumn{2}{|c|}{ دكتور اه } & \multicolumn{2}{|c|}{ ماجستير } & \multirow{3}{*}{ المؤهل } \\
\hline 84 & \multicolumn{2}{|c|}{50} & \multicolumn{2}{|c|}{34} & \\
\hline$\% 100$ & \multicolumn{2}{|c|}{$\% 59.5$} & \multicolumn{2}{|c|}{$\% 40.5$} & \\
\hline المجموع & أستاذ & أستاذ مساعد & مدرس & مدرس مساعد & \multirow{3}{*}{ اللعبي } \\
\hline 84 & 12 & 21 & 26 & 25 & \\
\hline$\% 100$ & $\% 14.3$ & $\% 25$ & $\% 31$ & $\% 29.7$ & \\
\hline المجموع & 31 سنة فأكثر & 21-30 سنة & 11-20 سنة & 10 سنة فأقل & \multirow{3}{*}{ الاجمالية الخدمة } \\
\hline 84 & 20 & 5 & 25 & 34 & \\
\hline$\% 100$ & $\% 23.8$ & $\% 6$ & $\% 29.8$ & $\% 40.5$ & \\
\hline
\end{tabular}

المصدر : من اعداد الباحثان.

المبحث الثاني: وصف متغيرات البحث اعثن أولاً. وصف متغير ممارسات إدارة الموارد البشرية الخضراء: يستعرض هذا المبحث وصف البف متغير ات الدر اسة عبر تحليل آراء الأفراد المستجيبين، وذللك باستخدام الأساليب الإحصائية منل: التوزيع التكراري، والنسب المئوية، و الوسط الحسابي، والانحراف المعياري، ونسبة الاتفاق،

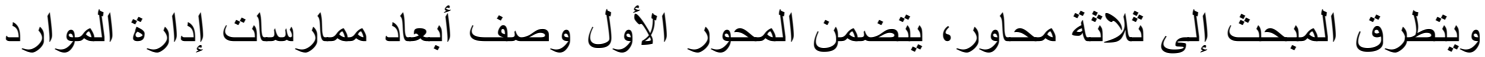
البشرية.

ا ـوصف بعد التوظيف الأخضر: تشير معطيات الجدول (T) إلى التوزيعات التكرارية والأوساط

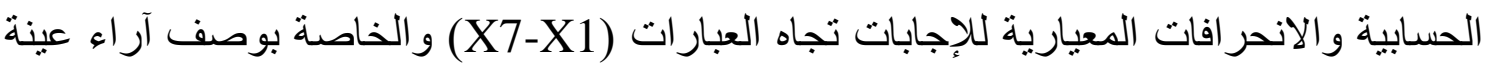

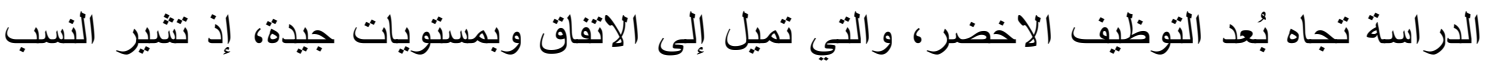
وبحسب المؤشر الكلي إلى أن (55.10\%) من الأفراد المستجيبين متفقون على مضمون هذه

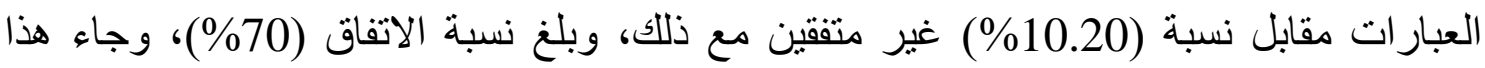

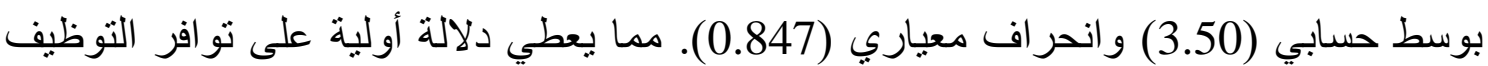
الاخضر الو اضحة لدى الجامعات المبحوثة وبمستوبات جيات جيدة.

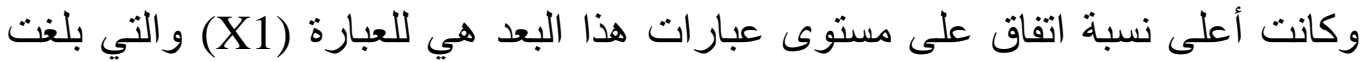

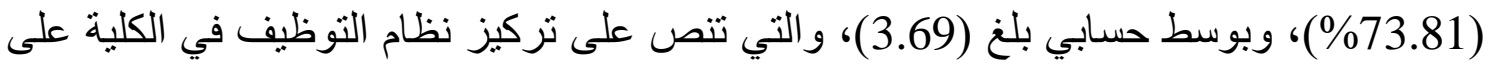

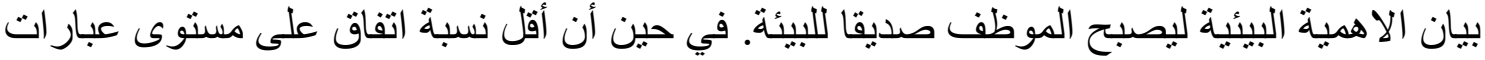
بعد التوظيف الاخضر كان للعبارة (X6) و التي بلغت (63.33\%)، وبوسط هـ حسابي بلغ (3.17)، و التي تتص على نظام التوظيف في الكلية يعمل على توظيف المرشحين الذين لديهم توجه لاتباع السياسات والممارسات البيئية الخضر اء. ץ. وصف بُعد التطوير والتدريب الأخضر: تشير معطيات الجدول (T) إلى التوزيعات التكرارية و الأوساط الحسابية و الانحر افات المعيارية للإجابات تجاه العبار ات (X14-X8) و والخاصة بوسن بوصف آر اء المستجيبين تجاه بعد التطوير و التدريب الأخضر و التي تميل إلى الاتفاق بمستويات جيدة، إذ إذابدان تشير النسب وبحسب المؤشر الكلي إلى أن (67.18\%) من المستجيبين متفقون على مضمون هذه ولهي العبار ات مقابل نسبة (8.50\%) غير متفقين مع مضمون عبار ات هذا البعد، وبلغت نسبة الاتفاق (74.83\%)، وجاء ذللك بوسط حسابي (3.74) و انحر اف معياري (0.840). وهذا يمثل نتيجة 
أولية على تو افر مؤشرات بعد التطوير والتدريب الاخضر لدى الجامعات المبحوثة وبمستويات

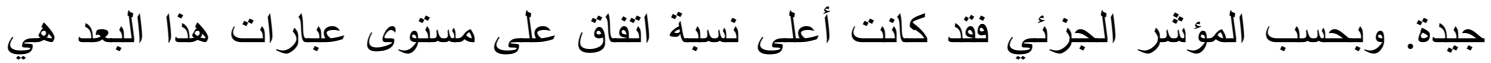
للعبارة (X14) و التي بلغت (81.67\%)، وبوسط حسابي بلغ (3.74)، و التي تشير إلى توفر الكلية المجال الاعضاء التدريسية ذوي الخبرة لنقل خبر اتهم الى زملائهم و الافادة منها. في حين أن أقل نسبة اتفاق على مستوى عبار ات بعد التطوير والتدريب الاخضر هي للعبارة (X11) و التي بلغت (65.71\%)، وبوسط حسابي بلغ (3.29)، و التي تنص على عمليات تطوير قدرات الموظفين في الكلية مبنية على الاسس البيئية. ". وصف بعد تقييم الأداء الأخضر: تشير معطيات الجدول (T) إلى التوزيعات التكرارية و الأوساط

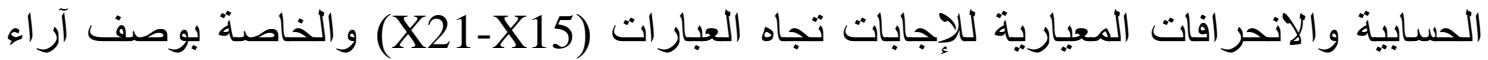
المستجيبين تجاه بعد تقييم الاداء الاخضر و التي تميل إلى الاتفاق وبمستويات جيدة، إذ تثير النسب وبحسب المؤشر الكلي إلى أن (68.37\%) من المستجيبين متفقون على مضمون هذه العبار ات

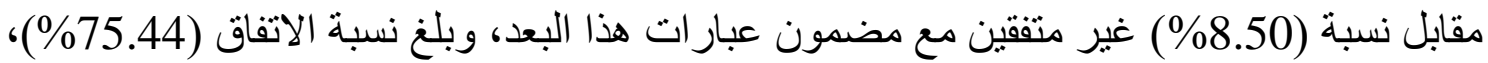
وجاء ذلك بوسط حسابي (3.77) و انحر اف معياري (0.902). و هذا يمثل نتيجة أولية على تو افر مؤشر ات وصف بعد تقييم الاداء الاخضر لدى الجامعات المبحوثة وبمستويات جيدة. وكانت أعلى نسبة اتفاق على مستوى عبار ات هذا البعد هي للعبارة (X18) و التي بلغت (82.86\%)، وبوسط حسابي بلغ (4.14)، والتي تشير إلى تربط الكلية انشطة اعضاء الهيئة التدريسية كالترقية وتحديد الاحتياجات التدريبية و الحوافز بعملية تقييم الأداء. في حين أن أقل نسبة

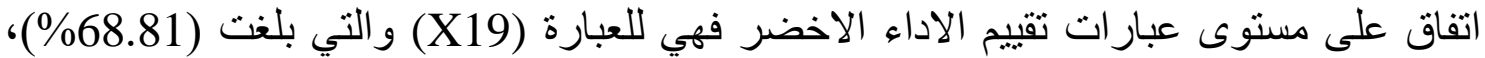
وبوسط حسابي بلغ (3.44)، و التي تتص على لدى ادارة الموارد البثرية في الكلية مؤشرات للأداء الاخضر الصديق للبيئة لإدارة وتقييم الاداء. ؛. وصف بعد التعويضات والمكافآت الأخضر: تثير معطيات الجدول (7) إلى التوزيعات التكر ارية والأوساط الحسابية والانحرافات المعيارية للإجابات تجاه العبارات (X28-X22) و والخاصة بوصف آراء المستجيبين تجاه بعد التعويضات والمكافآت الأخضر والتي تميل إلى الاتفاق وبمستويات جيدة، إذ تنير النسب وبحسب المؤشر الكلي إلى أن (49.83\%) من الأفراد المستجيبين متفقون على مضمون هذه العبار ات مقابل نسبة (20.41\%) غير متفقين مع مضمون

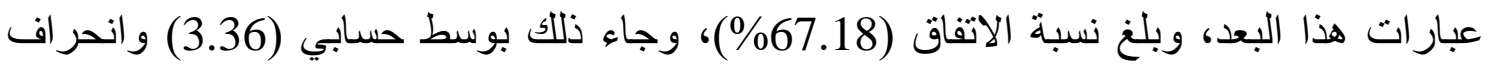
معياري (1.030). مما يؤشر وبشكل أولي توافر إلى مؤشرات بـات بعد التعويضات واتهات والمكافآت

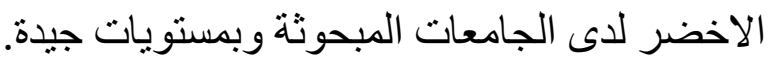
وكانت أعلى نسبة اتفاق على مستوى عبار ات هذا البعد هي للمؤشر (X26) و التي بلغت

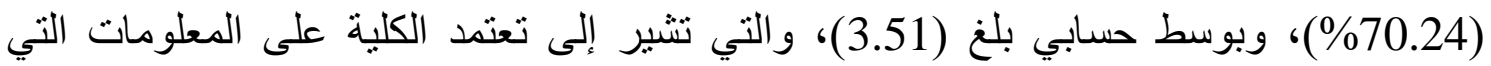
يوفرها نظم تقييم الاداء لغرض تحديد المكافآت والحوافز التي يستحقها أعضاء الهيئة التدريسية

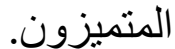


الجدول (7): وصف أبعاد ممارسات إدارة المو ارد البشرية الخضر اء

\begin{tabular}{|c|c|c|c|c|c|c|c|c|c|c|c|c|c|c|}
\hline \multirow{3}{*}{ الآنفبة } & \multirow{3}{*}{ المعياري } & \multirow{3}{*}{ الحسابي } & \multicolumn{2}{|c|}{ لا اتفقلى بشدة } & \multicolumn{2}{|c|}{ لا اتفى } & \multicolumn{2}{|c|}{ هحائ } & \multicolumn{2}{|c|}{ اتففى } & \multicolumn{2}{|c|}{ اتفنى بثدة } & \multirow{3}{*}{ العبزات } & \multirow{3}{*}{ أبعاد متفيز } \\
\hline & & & \multicolumn{2}{|c|}{1} & \multicolumn{2}{|c|}{2} & \multicolumn{2}{|c|}{3} & \multicolumn{2}{|c|}{ 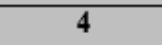 } & \multicolumn{2}{|c|}{5} & & \\
\hline & & & $\%$ & Freq. & $\%$ & Freq. & $\%$ & Freq. & $\%$ & Freq. & $\%$ & Freq. & & \\
\hline 73.81 & 0.878 & 3.69 & 0.00 & 0 & 11.90 & 10 & 22.62 & 19 & 50.00 & 42 & \begin{tabular}{|l|}
15.48 \\
\end{tabular} & 13 & $\mathrm{X} 1$ & \multirow{7}{*}{ الألتضظنيف } \\
\hline 72.38 & 0.790 & 3.62 & 1.19 & 1 & 8.33 & 7 & 25.00 & 21 & 58.33 & 49 & \begin{tabular}{|l|}
7.14 \\
\end{tabular} & 6 & $\mathrm{X} 2$ & \\
\hline 70.48 & 0.857 & 3.52 & 1.19 & 1 & 10.71 & 9 & 32.14 & 27 & 46.43 & 39 & \begin{tabular}{|l|}
9.52 \\
\end{tabular} & 8 & $\mathrm{X} 3$ & \\
\hline 68.57 & 0.733 & 3.43 & 0.00 & 0 & 10.71 & 9 & 39.29 & 33 & 46.43 & 39 & \begin{tabular}{|l|}
3.57 \\
\end{tabular} & 3 & $\mathrm{X} 4$ & \\
\hline 70.00 & 0.885 & 3.50 & 0.00 & 0 & 11.90 & 10 & 40.48 & 34 & 33.33 & 28 & 14.29 & 12 & $\mathrm{X} 5$ & \\
\hline 63.33 & 0.946 & 3.17 & 1.19 & 1 & 4.76 & 4 & 34.52 & 29 & 35.71 & 30 & 11.90 & 10 & X6 & \\
\hline 71.43 & 0.840 & 3.57 & 0.00 & 0 & 9.52 & 8 & 36.90 & 31 & 40.48 & 34 & \begin{tabular}{|l|}
13.10 \\
\end{tabular} & 11 & $\mathrm{X} 7$ & \\
\hline \multirow{2}{*}{70.00} & \multirow{2}{*}{0.847} & \multirow{2}{*}{3.50} & \multicolumn{2}{|c|}{0.51} & \multirow{2}{*}{\multicolumn{2}{|c|}{9.6}} & \multirow{2}{*}{\multicolumn{2}{|c|}{32.99}} & & & 10 & & & \\
\hline & & & & & & & & & & & 10 & & & \\
\hline 77.62 & 0.827 & 3.88 & 0.00 & 0 & 5.95 & 5 & 22.62 & 19 & 48.81 & 41 & 22.62 & 19 & $\mathrm{X} 8$ & \\
\hline 77.62 & 0.767 & 3.88 & 0.00 & 0 & 5.95 & 5 & \begin{tabular}{|l|}
17.86 \\
\end{tabular} & 15 & 58.33 & 49 & \begin{tabular}{|l|}
17.86 \\
\end{tabular} & 15 & $\mathrm{X} 9$ & \\
\hline 72.14 & 0.970 & 3.61 & 2.38 & 2 & 13.10 & 11 & 20.24 & 17 & 50.00 & 42 & 14.29 & 12 & $\mathrm{X} 10$ & التطوير \\
\hline 65.71 & 0.886 & 3.29 & 3.57 & 3 & 14.29 & 12 & 35.71 & 30 & 42.86 & 36 & \begin{tabular}{|l|l|}
3.57 \\
\end{tabular} & 3 & $\mathrm{X} 11$ & تَريب \\
\hline 71.67 & 0.853 & 3.58 & 3.57 & 3 & 2.38 & 2 & 36.90 & 31 & 46.43 & 39 & \begin{tabular}{|l|}
10.71 \\
\end{tabular} & 9 & $\mathrm{X} 12$ & \\
\hline 77.38 & 0.724 & 3.87 & 0.00 & 0 & 3.57 & 3 & 22.62 & 19 & 57.14 & 48 & 16.67 & 14 & $\mathrm{X} 13$ & \\
\hline 81.67 & 0.853 & 4.08 & 1.19 & 1 & 3.57 & 3 & \begin{tabular}{|l|}
14.29 \\
\end{tabular} & 12 & 47.62 & 40 & 33.33 & 28 & $\mathrm{X} 14$ & \\
\hline 7483 & 0840 & 374 & & & & & & & & & 17. & & & \\
\hline 17.0 & 0.070 & 5.17 & & & & & & & & & 18 & & & \\
\hline 72.86 & 0.831 & 3.64 & 1.19 & 1 & 8.33 & 7 & 26.19 & 22 & 53.57 & 45 & \begin{tabular}{|l|}
10.71 \\
\end{tabular} & 9 & $\mathrm{X} 15$ & \\
\hline 75.71 & 0.995 & 3.79 & 4.76 & 4 & 3.57 & 3 & 22.62 & 19 & 46.43 & 39 & 22.62 & 19 & $\mathrm{X} 16$ & \\
\hline 79.76 & 0.857 & 3.99 & 1.19 & 1 & 3.57 & 3 & \begin{tabular}{|l|}
19.05 \\
\end{tabular} & 16 & 47.62 & 40 & 28.57 & 24 & $\mathrm{X} 17$ & \\
\hline 82.86 & 0.852 & 4.14 & 2.38 & 2 & 2.38 & 2 & \begin{tabular}{|l|l|}
8.33 \\
\end{tabular} & 7 & 52.38 & 44 & 34.52 & 29 & $\mathrm{X} 18$ & \\
\hline 68.81 & 0.910 & 3.44 & 4.76 & 4 & 5.95 & 5 & 38.10 & 32 & 42.86 & 36 & 8.33 & 7 & $\mathrm{X} 19$ & \\
\hline 76.43 & 0.894 & 3.82 & 2.38 & 2 & 4.76 & 4 & 21.43 & 18 & 51.19 & 43 & 20.24 & 17 & $\mathrm{X} 20$ & \\
\hline 71.67 & 0.972 & 3.58 & 2.38 & 2 & 11.90 & 10 & 26.19 & 22 & 44.05 & 37 & 15.48 & 13 & $\mathrm{X} 21$ & \\
\hline 75,44 & 0.902 & 377 & & & & & & & & & 20. & & & المع \\
\hline & & & & & & & & & & & 37 & & & \\
\hline 68.81 & 1.134 & 3.44 & 5.95 & 5 & 15.48 & 13 & 25.00 & 21 & 35.71 & 30 & \begin{tabular}{|l|l|} 
\\
\end{tabular} & 15 & $\mathrm{X} 22$ & \\
\hline 68.57 & 1.009 & 3.43 & 3.57 & 3 & 14.29 & 12 & 30.95 & 26 & 38.10 & 32 & 13.10 & 11 & $\mathrm{X} 23$ & \\
\hline 65.95 & 0.902 & 3.30 & 3.57 & 3 & 13.10 & 11 & 39.29 & 33 & 38.10 & 32 & 5.95 & 5 & $\mathrm{X} 24$ & ليضات \\
\hline 65.95 & 0.967 & 3.30 & 4.76 & 4 & 15.48 & 13 & 30.95 & 26 & 42.86 & 36 & 5.95 & 5 & $\mathrm{X} 25$ & ركافآت \\
\hline 70.24 & 1.081 & 3.51 & 2.38 & 2 & 19.05 & 16 & 22.62 & 19 & 36.90 & 31 & 19.05 & 16 & $\mathrm{X} 26$ & لأخضر \\
\hline 64.52 & 1.022 & 3.23 & 5.95 & 5 & 16.67 & 14 & 34.52 & 29 & 34.52 & 29 & 8.33 & 7 & $\mathrm{X} 27$ & \\
\hline 66.19 & 1.097 & 3.31 & 8.33 & 7 & 14.29 & 12 & 25.00 & 21 & 42.86 & 36 & \begin{tabular}{|l|l|}
9.52 \\
\end{tabular} & 8 & $\mathrm{X} 28$ & \\
\hline 67.18 & 1030 & 336 & & & & & & & & & 11. & & & \\
\hline & & & & & & & & & & & & & & \\
\hline
\end{tabular}

المصدر : إعداد الباحثان على وفق نتائج التحليل الإحصائي.

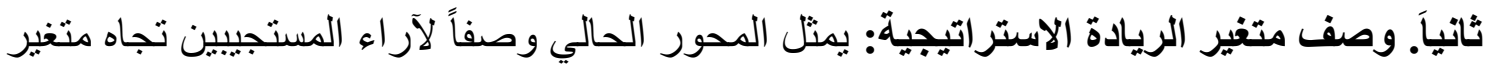

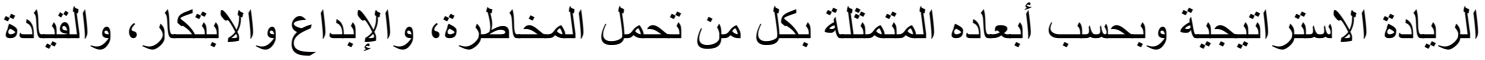

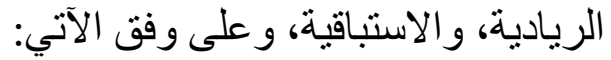
ا ـوصف بعد تحمل المخاطرة: تشير إجابات المستجيبين في الجدول (V) إلى التوزيعات التكرارية والأوساط الحسابية والانحر افات المعيارية للإجابات الخاصة بمضمون العبارات (Y7-Y1) و الخاصة بوصف آراء المستجيبين تجاه وصف بعد تحمل المخاطرة والتي تميل إلى الاتفاق وبمستويات جيدة، إذ نشير النسب وبحسب المؤشر الكلي إلى أن (54.59\%) من الأفراد 
المستجييين متفقون على مضمون هذه العبار ات مقابل نسبة (15.82\%) غير متفقين مع هذا البعد، وبلغ نسبة الاتفاق (69.73\%)، وجاء ذللك بوسط حسابي (3.49) وانحر اف معياري (20.950).

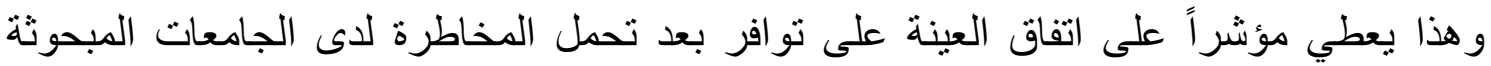

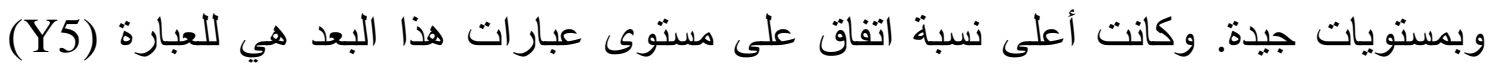

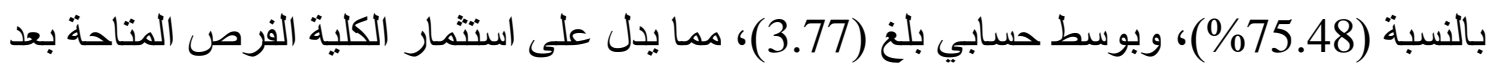

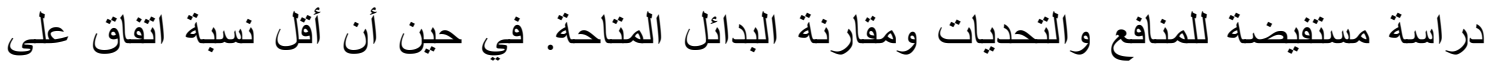

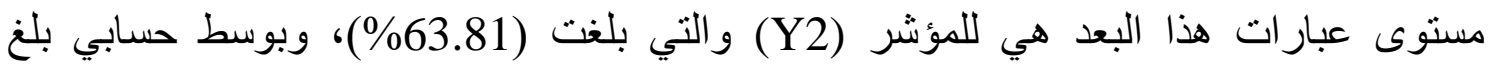

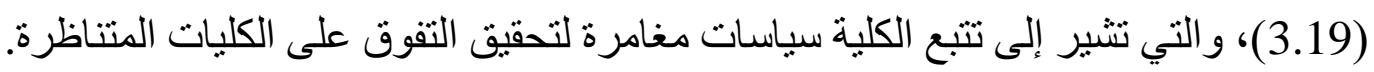

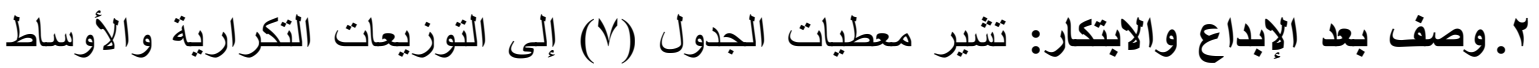

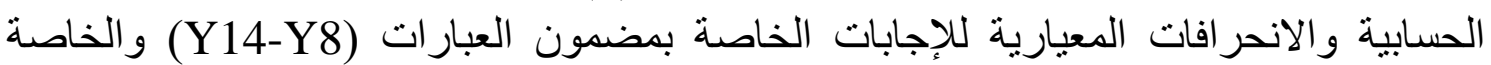

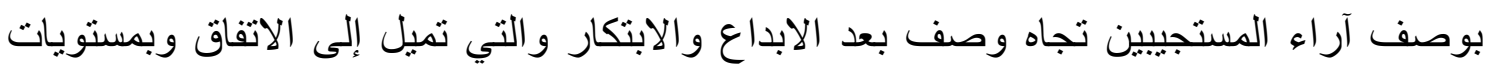

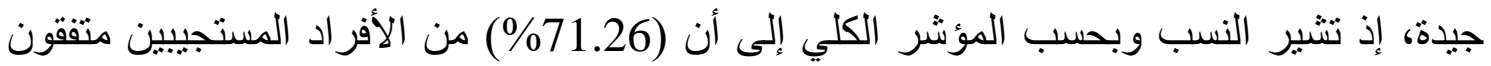

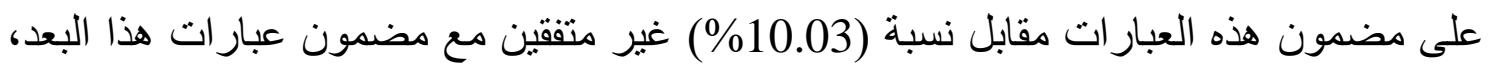

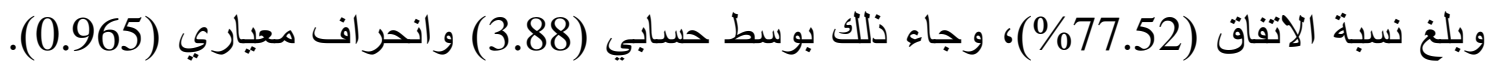

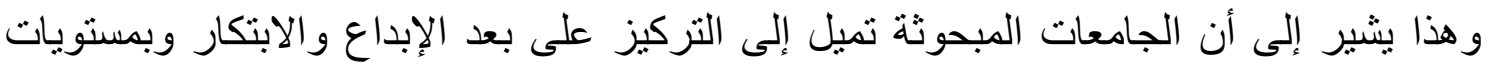

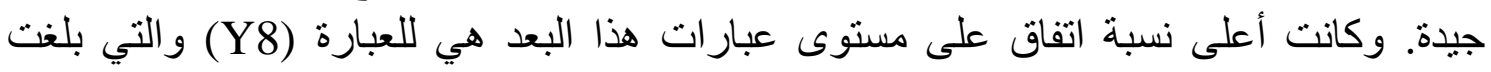

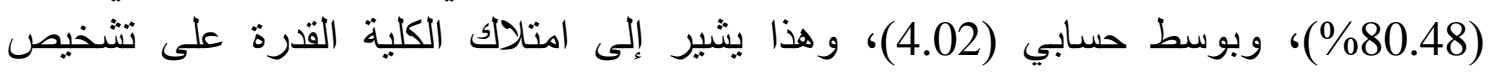

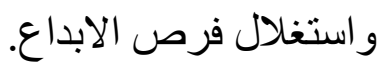

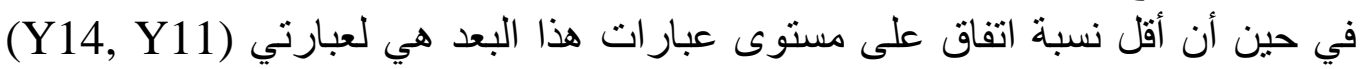

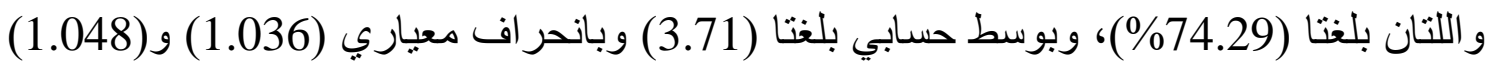

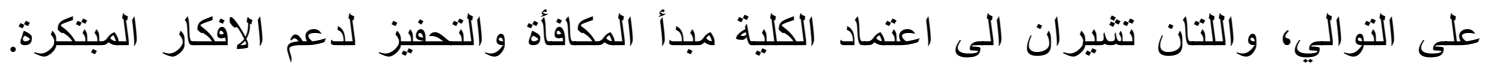

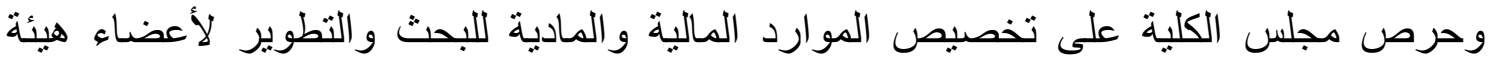

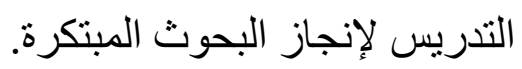
r.وصف بعد القيادة الريادية: تثنير معطيات الجدول (V) إلى التوزيعات التكرارية والأوساط

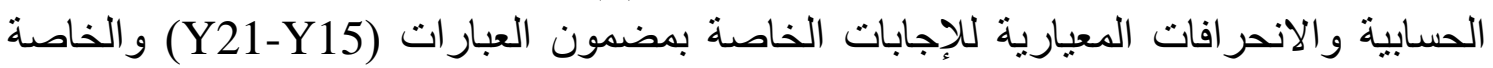

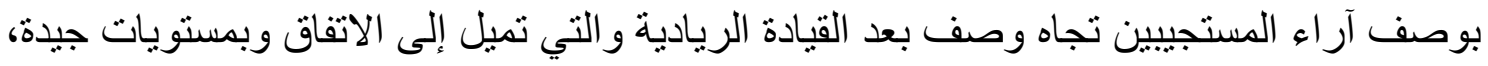

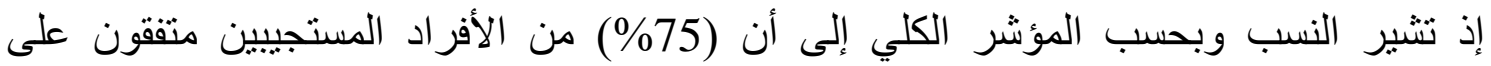

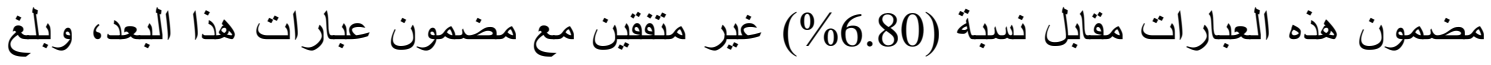

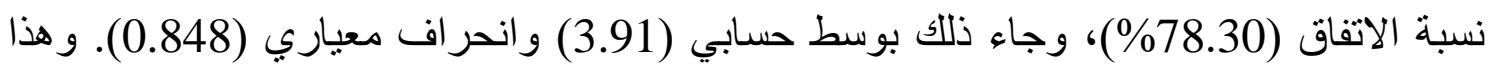

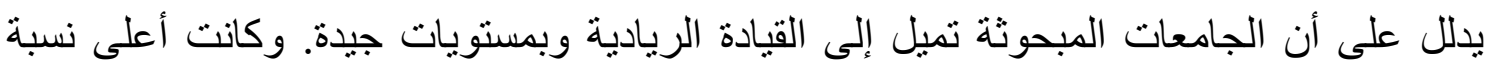

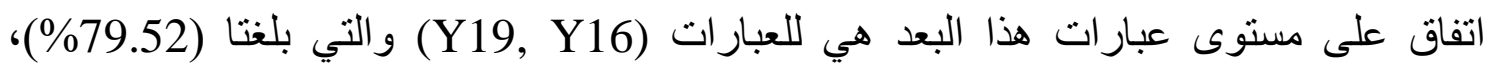

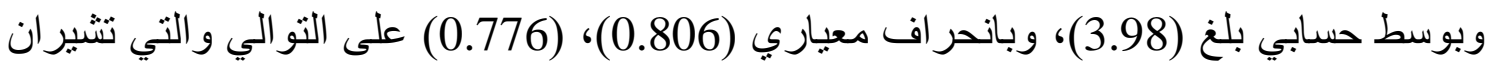

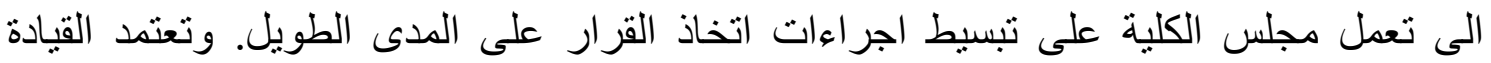

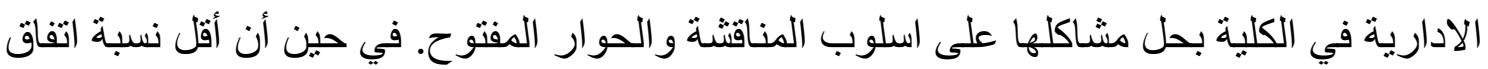

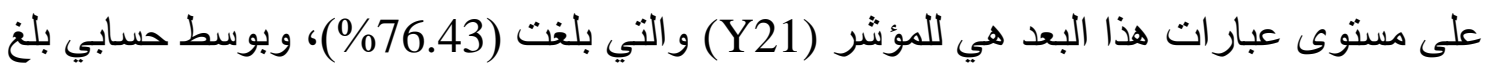




\begin{tabular}{|c|c|c|c|c|c|c|c|c|c|c|c|c|c|c|}
\hline 79.05 & 0.917 & 3.95 & 1.19 & 1 & 7.14 & 6 & 15.48 & 13 & 47.62 & 40 & 28.57 & 24 & Y15 & \multirow{7}{*}{ الريائية } \\
\hline 79.52 & 0.806 & 3.98 & 0.00 & 0 & 4.76 & 4 & 19.05 & 16 & 50.00 & 42 & 26.19 & 22 & Y16 & \\
\hline 76.90 & 0.938 & 3.85 & 2.38 & 2 & 7.14 & 6 & 16.67 & 14 & 51.19 & 43 & 22.62 & 19 & Y17 & \\
\hline 77.38 & 0.757 & 3.87 & 0.00 & 0 & 3.57 & 3 & 25.00 & 21 & 52.38 & 44 & 19.05 & 16 & Y18 & \\
\hline 79.52 & 0.776 & 3.98 & 0.00 & 0 & 5.95 & 5 & 13.10 & 11 & 58.33 & 49 & 22.62 & 19 & Y19 & \\
\hline 79.29 & 0.768 & 3.96 & 0.00 & 0 & 3.57 & 3 & 20.24 & 17 & 52.38 & 44 & 23.81 & 20 & Y20 & \\
\hline 76.43 & 0.971 & 3.82 & 1.19 & 1 & 10.71 & 9 & 17.86 & 15 & 45.24 & 38 & 25.00 & 21 & Y21 & \\
\hline \multirow{2}{*}{78.30} & \multirow{2}{*}{0.848} & \multirow{2}{*}{3.91} & \multicolumn{2}{|c|}{0.68} & \multirow{2}{*}{\multicolumn{2}{|c|}{6.12}} & \multirow{2}{*}{\multicolumn{2}{|c|}{18.20}} & \multicolumn{4}{|c|}{23.98} & \multirow{2}{*}{\multicolumn{2}{|c|}{ ألمعل }} \\
\hline & & & \multicolumn{2}{|c|}{6.80} & & & & & \multicolumn{4}{|c|}{75.00} & & \\
\hline 81.43 & 0.902 & 4.07 & 0.00 & 0 & 7.14 & 6 & 15.48 & 13 & 40.48 & 34 & 36.90 & 31 & Y22 & \multirow{7}{*}{ الاسنتبالتية } \\
\hline 80.48 & 0.918 & 4.02 & 2.38 & 2 & 5.95 & 5 & 8.33 & 7 & 53.57 & 45 & 29.76 & 25 & Y23 & \\
\hline 80.48 & 0.931 & 4.02 & 2.38 & 2 & 4.76 & 4 & 13.10 & 11 & 47.62 & 40 & 32.14 & 27 & Y24 & \\
\hline 82.14 & 0.865 & 4.11 & 2.38 & 2 & 2.38 & 2 & 10.71 & 9 & 51.19 & 43 & 33.33 & 28 & Y25 & \\
\hline 79.52 & 0.944 & 3.98 & 3.57 & 3 & 3.57 & 3 & 13.10 & 11 & 51.19 & 43 & 28.57 & 24 & Y26 & \\
\hline 76.43 & 0.946 & 3.82 & 2.38 & 2 & 5.95 & 5 & 22.62 & 19 & 45.24 & 38 & 23.81 & 20 & Y27 & \\
\hline 82.62 & 0.875 & 4.13 & 2.38 & 2 & 3.57 & 3 & 7.14 & 6 & 52.38 & 44 & 34.52 & 29 & Y28 & \\
\hline \multirow[t]{2}{*}{80.44} & \multirow[t]{2}{*}{0.912} & \multirow[t]{2}{*}{4.02} & \multicolumn{2}{|c|}{2.21} & \multirow{2}{*}{\multicolumn{2}{|c|}{4.76}} & \multirow{2}{*}{\multicolumn{2}{|c|}{12.93}} & \multicolumn{4}{|c|}{\begin{tabular}{r|r|} 
& 31.29 \\
\end{tabular}} & \multirow{2}{*}{\multicolumn{2}{|c|}{ المعلل }} \\
\hline & & & \multicolumn{2}{|c|}{6.97} & & & & & \multicolumn{4}{|c|}{80.10} & & \\
\hline
\end{tabular}

المصدر : إعداد الباحثنان على وفق نتائج التحليل الإحصائي.

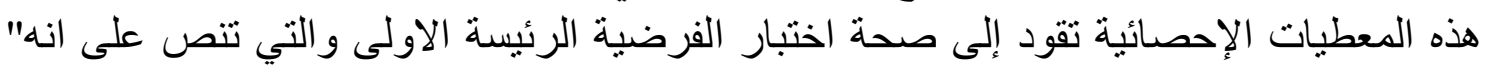

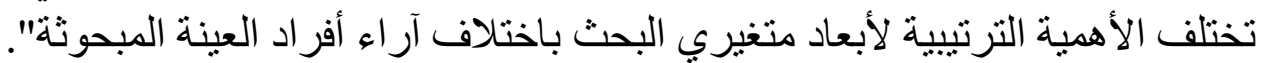

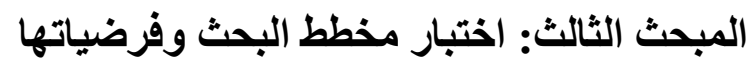

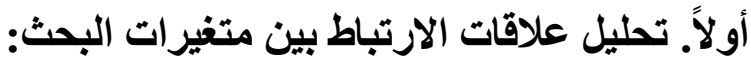

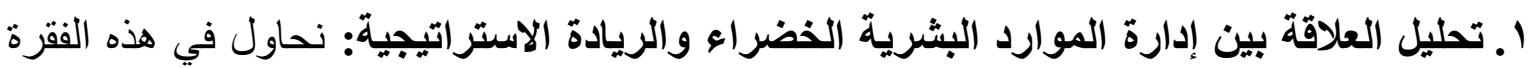

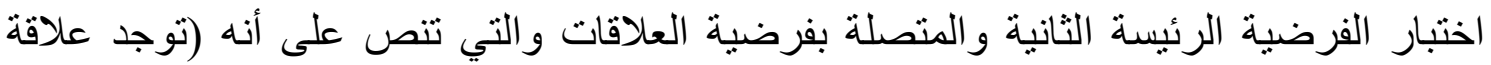

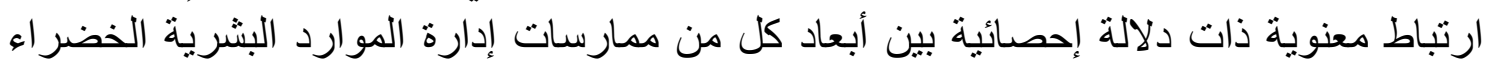

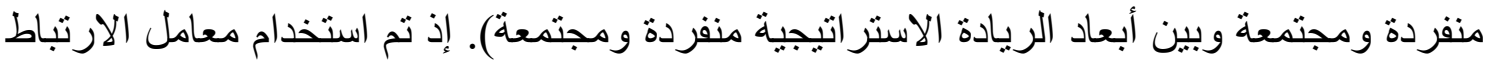

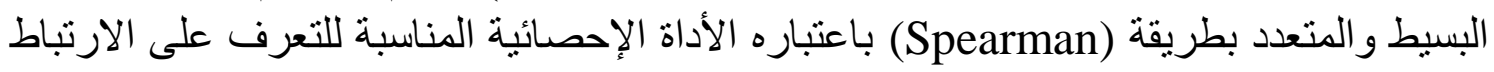
بين متغير ات الدر اسة ذات البيانات الوصفية، وسيتم التحقق من مدى صحة تللك الفرضية وذللك كما

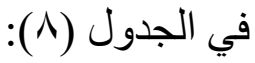

الجدول (^): علاقات الارتباط بين متغير ات البحث منفردة ومجتمعة

\begin{tabular}{|c|c|c|c|c|c|c|}
\hline الهزئر & \multicolumn{4}{|c|}{ الريادة الاستر اتبيجية (Y) } & \multirow[t]{2}{*}{ المنظير المقدل } & \multirow[b]{2}{*}{ المنفير المستقل } \\
\hline الكلي & الاستباقية & الثيادة الزريائة & الابداع والابتكر & تحل المخاطرة & & \\
\hline $0.503^{* *}$ & $0.384^{* *}$ & $0.398 * *$ & $0.552^{* *}$ & $0.417^{* *}$ & التُوظيف الاخضر & \multirow{4}{*}{ الموارد البشرية ادارة } \\
\hline $0.572^{* *}$ & $0.432 * *$ & $0.555^{* *}$ & $0.686^{* * *}$ & $0.337^{* *}$ & ألتطويز والثدريب الاخضر & \\
\hline $0.545^{* *}$ & $0.437^{* *}$ & $0.476 * *$ & $0.600^{* *}$ & $0.336^{* *}$ & ققيليم الاداء الاخضز & \\
\hline 0.539 ** & $0.428^{* *}$ & $0.482 * *$ & $0.598 * *$ & $0.349^{* *}$ & التعويضنات و المكافآت الاخضر & \\
\hline $0.605^{* *}$ & $0.873^{* *}$ & $0.889 * *$ & $0.915^{* * *}$ & $0.726^{* *}$ & المزئر الكلي & \\
\hline
\end{tabular}

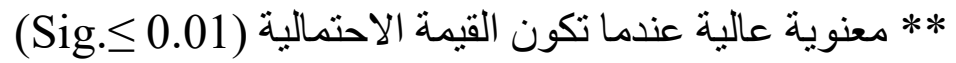

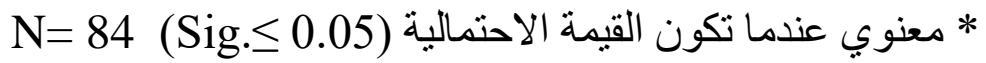
المصدر : إعداد الباحثنان على وفق نتائج التحليل الاحصائي. 
وبذلك فإن نتائج تحليل العلاقات على المستوى الجزئي تدعم وبقوة نتائج تحليل العلاقات

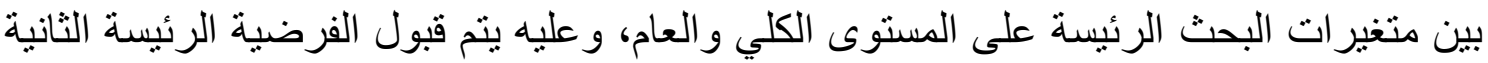

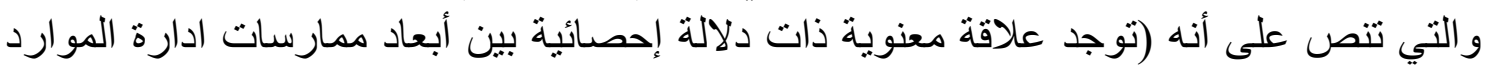

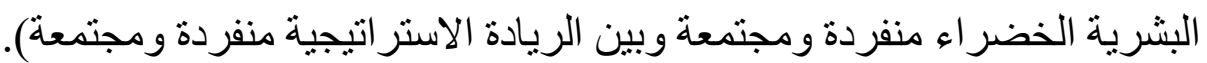

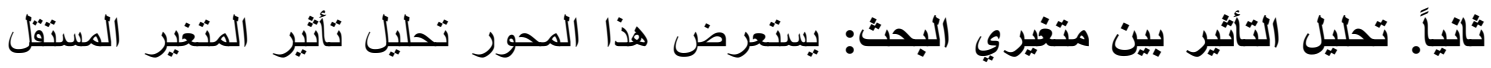
المتمثلة بممارسات ادارة الموارد البشرية الخضراء في المتغير المعتمد المتمنل في الريادة الاستراتيجية على المستوى الكلى والجزئي، ولاختبار الفرضية الرئيسة الثالثة ومتفرعاتها تم

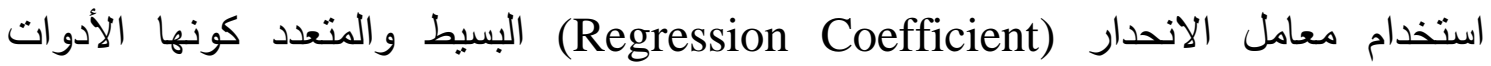
الإحصائية المناسبة للتعرف على علاقات التأثير بين متغيرات الدراسة و أبعادها، إذ سيتم التحقق من مدى صحة تللك الفرضيات وذللك كما يأتي:

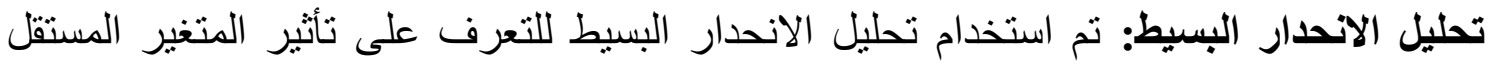
(ممارسات ادارة الموارد البشرية الخضراء) في المتغير المعتمد (الريادة الاستراتيجية) و وعلى الإنى

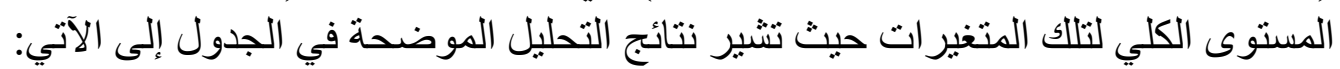

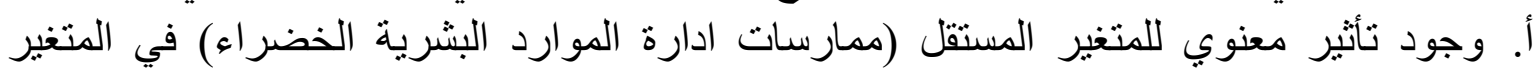
المستجيب أو المعتمد (الريادة الاستراتيجية) و على مستوى المؤشر الكلي، إذ بلغت قيمة مستوى المعنوية (P-Value) المحسوبة (0.000) وهي أقل بكثير من قيمة مستوى المعنوية الافتر اضي واضي

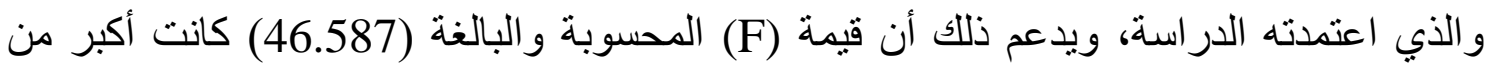
قيمتها الجدولية والبالغة (3.957) وبدرجات حرية (1، 82) مما يشير إلى معنوية التأثير و عند

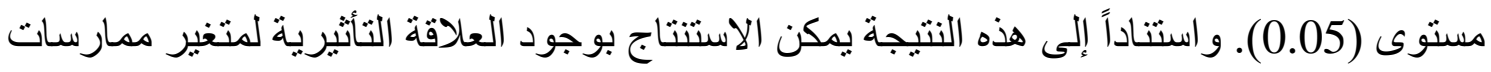

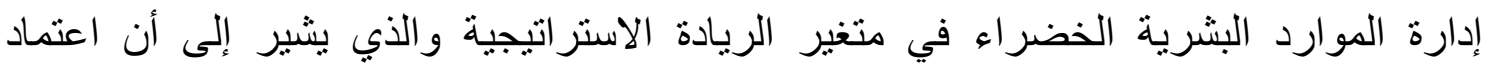

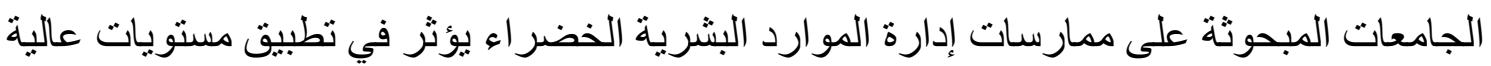

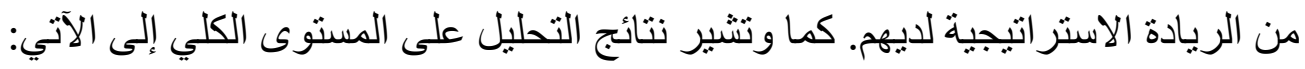

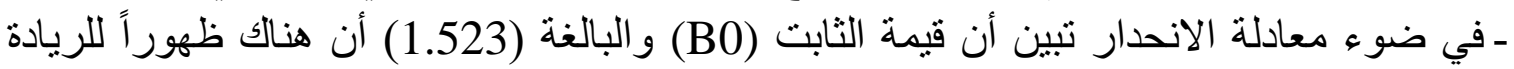

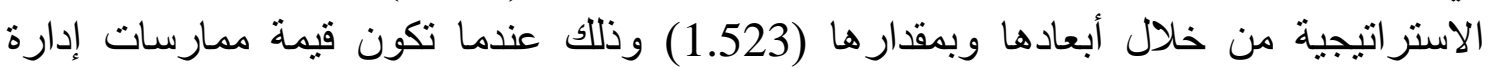

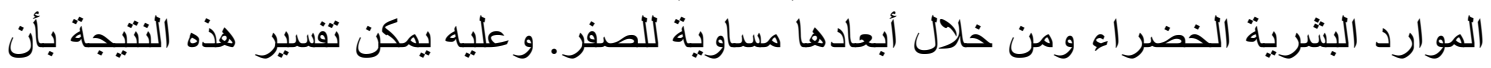

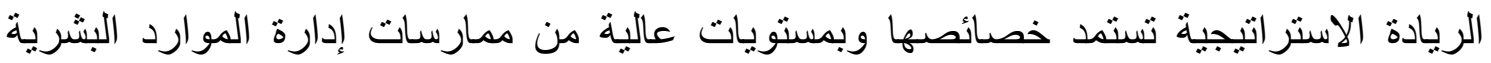

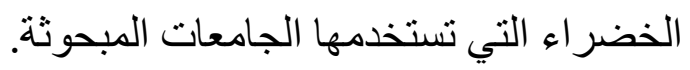

ـ أما قيمة الميل الحدي (B1) فقد بلغت (0.639) وهي دلالة على أن تغير اً مقداره و احد (1) في

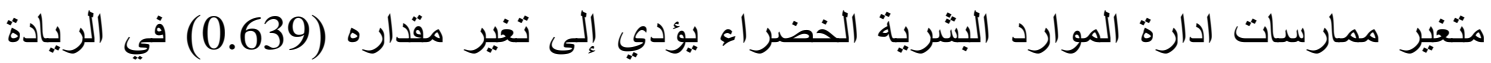
الاستراتيجية، وهو تغير كبير بمكن الاستناد عليه في تفسير العلاقة التأثيرية للمتغير المستقل

ممارسات ادارة الموارد البشرية الخضر اء في المتغير المعتمد الريادة الاستر اتيجية. ـ أما قيمة (R2) فقد بلغت (0.362) و التي تشير إلى أن ما نسبته (36.2\%) من التغير الذي يحدث في الريادة الاستر اتيجية يعود إلى ممارسات ادارة الموارد البشرية الخضراء، أي أن القئ القيمة

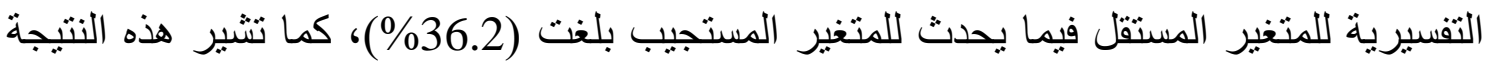

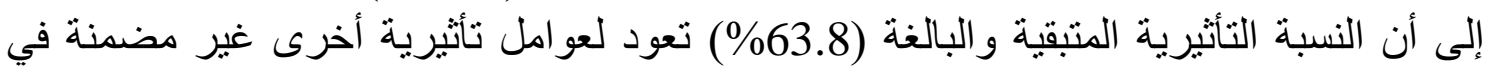
الأنموذج الافتر اضي الذي أعتمد في الدر اسة الحالية. 
الجدول (9): تأثنير إدارة الموارد البشرية الخضر اء في الريادة الاستر اتيجية على المستوى الكلي

\begin{tabular}{|c|c|c|c|c|}
\hline \multicolumn{4}{|c|}{ الريادة الاستر اتيجية } & \multirow{2}{*}{ المتغير المستُقل المتغير المعتمد } \\
\hline $\mathbf{R 2}$ & $\mathbf{F}$ & B1 & الثابت-B0 & \\
\hline$\% 36.2$ & $\begin{array}{c}46.587 \\
\text { Sig.(0.000)** }\end{array}$ & $\begin{array}{c}0.684 \\
\mathrm{t}(6.825) \\
\text { Sig.(0.000)** }\end{array}$ & $\begin{array}{c}1.523 \\
t(4.459) \\
\text { Sig.(0.000)** }\end{array}$ & الموارد البشرية الخدارة \\
\hline
\end{tabular}

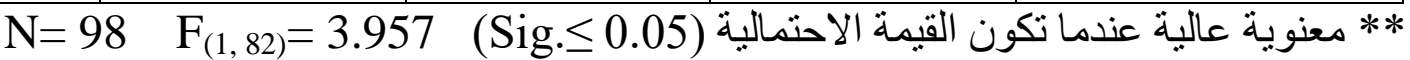
المصدر: إعداد الباحثان على وفق نتائج التحليل الاحصنائي.

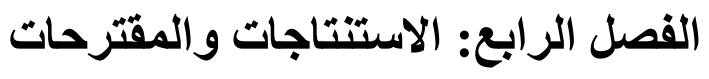

1. اظهرت نتائج الوصف لخصائص المستجيبين بأن أغلبية أعضاء مجالس الكليات في الجامعات

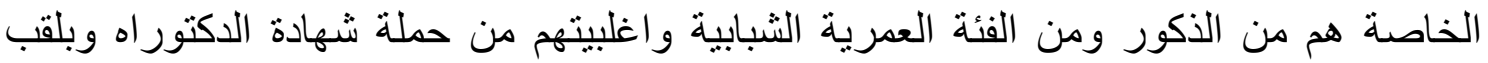

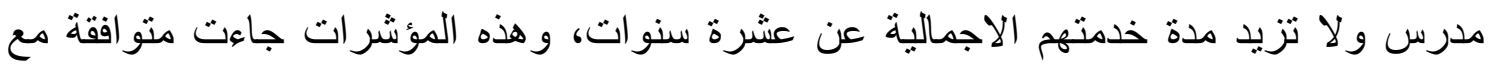

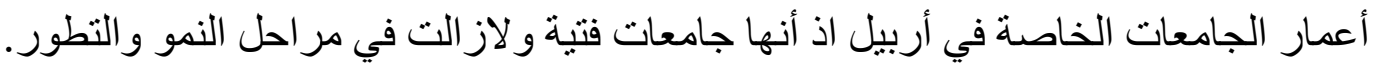

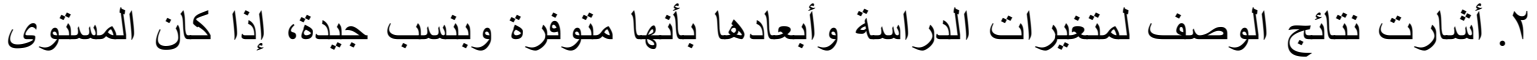
عالياً للتوظيف الاخضر من خلال تركيز الكليات على توظيف العاملين المؤمنين بأهمية المحافظة

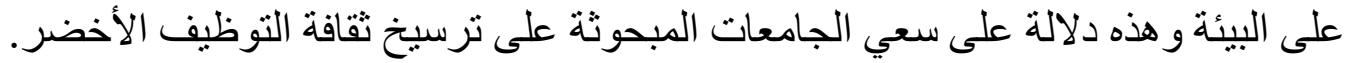

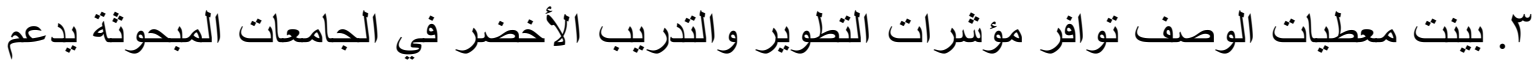

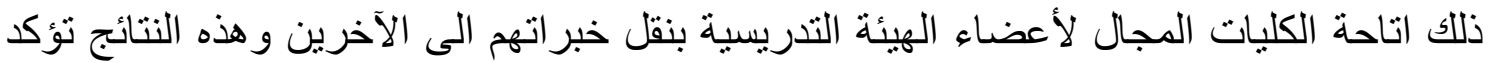

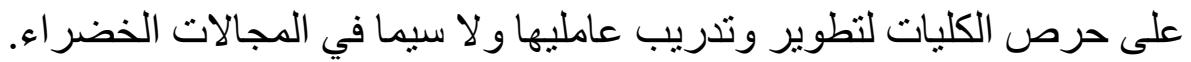

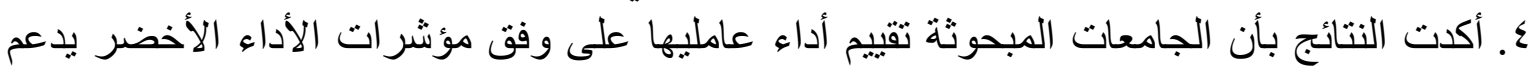

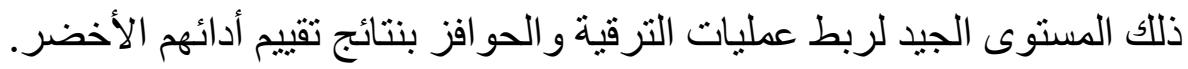

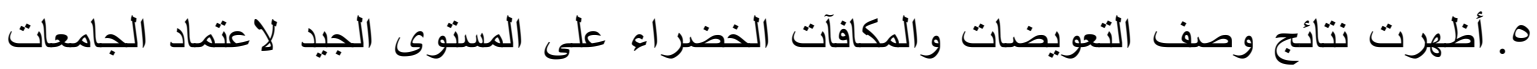
المبحوثة على المعلومات التي يوفر ها نظام تقييم الأداء في منح التعويضات و المكافآت و هذه النتيجة تدعم التوجه المعاصر للجامعات في مدينة أربيل ومحاكاتها للجامعات المرموقة عالمياً والته والتي تمنح

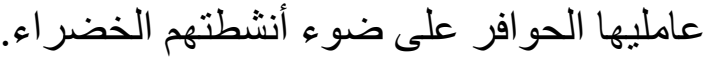
7 ا أكدت نتائج وصف متغير الريادة الاستر اتيجية تو افر كافة أبعادها وبمستويات جيدة، اذ بينت النتائج قدرة الجامعات المبحوثة على تحمل المخاطرة من خلال استثمار الفرص بعد دراسة مستفيضة للمنافع و التحديات المقترنة بها و هذه دلالة على حرص الجامعات لقياس المخاطرة واحتساب الكلفة و المنافع للفرص البديلة. V. أن الإبداع و الابتكار تعد من الامور المهمة التي تركز عليها الجامعات المبحوثة لأن النتائج أكدت

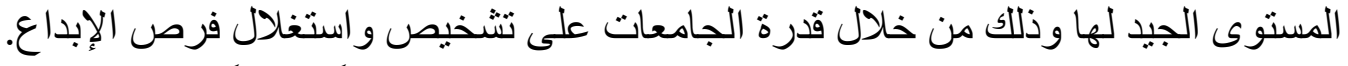

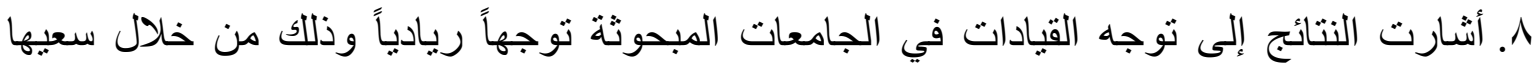
لتبسيط الإجر اءات وتبنيها لأسلوب المناقتة و الحوار المفتوح في حل المشاكل، كل ذللك يؤكد إيمان أعضاء مجالس الكليات بمبادئ ومفاهيم الريادة الاستر اتيجية. 
ثنانياً. المقترحات:

ا. ضرورة تركيز الجامعات المبحوثة على تكليف الاناث بالمهام الإدارية كأعضاء في مجالس الكليات والاستفادة من بعض خصائصهم كالتعاون و التحمل و القدرة على التفكير المتعدد وكذاكي

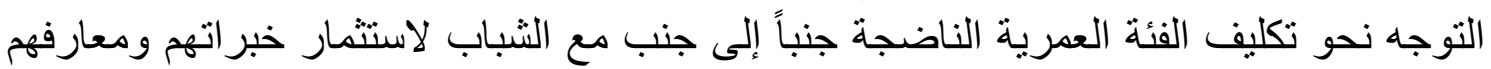
من خلال تغيير انظمة الاستقطاب في الجامعات المبحوثة

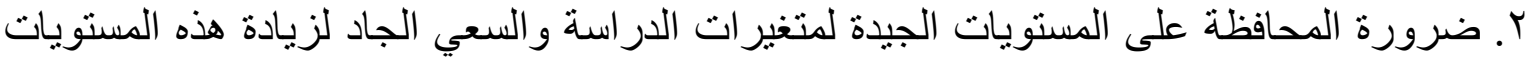

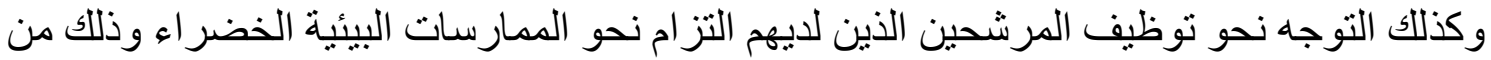
خلال تغيير أسس و إجر اءات الاختيار و التعيين في تللك الجامعات.

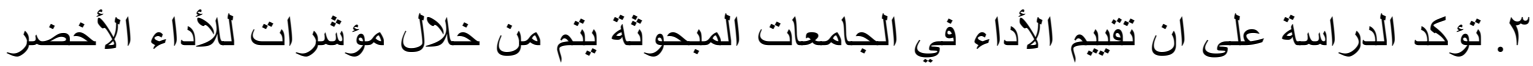
وذللك من خلال إدر اج الأنشطة الخضر اء كمعايير للتقييم في نماذج قياس الأداء وتقييمها.

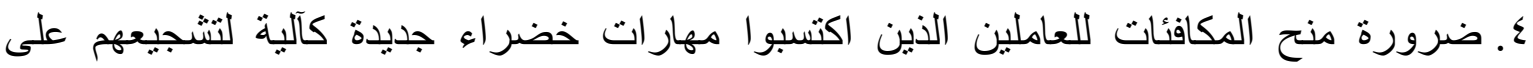
الاستمر ار ودعم الأخرين في هذا المجال. ๑. على الكليات المبحوثة تبني سياسات المغامرة بهدف التفوق على الكليات المتناظرة وذلك من خلال تشكيل لجان أو وحدات لإدارة المخاطرة ودر استها.

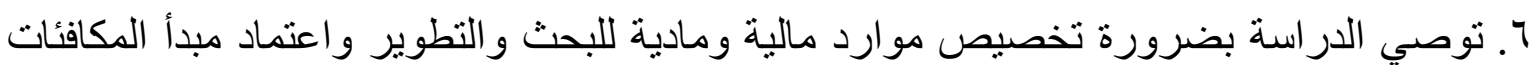

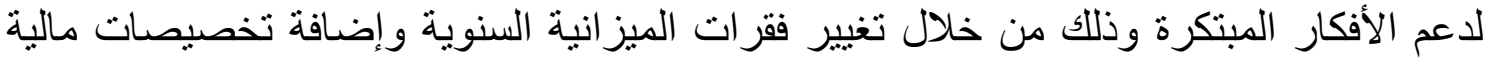
للبحث و التطوير. المصادر

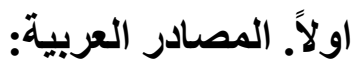

ا ـ الأغا، وفيق، (9 . . ب)، الريادة في الثركات العربية بمنظور استر اتيجي، مجلة جامعة الأزهر

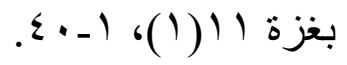

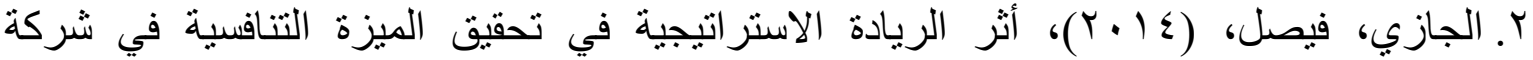
الاتصالات الأردنية، رسالة ماجستير، قسم الإدارة العامة، جامعة مؤتة_الأردن.

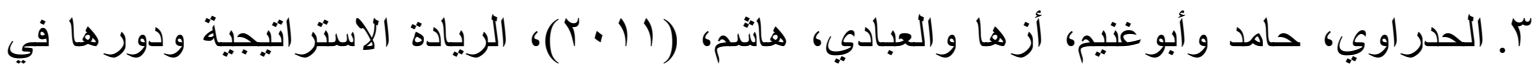

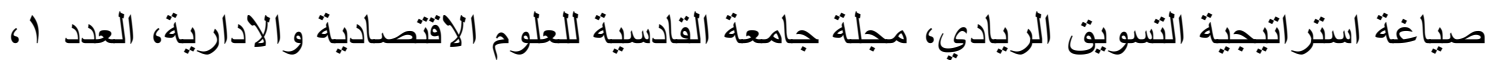

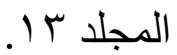

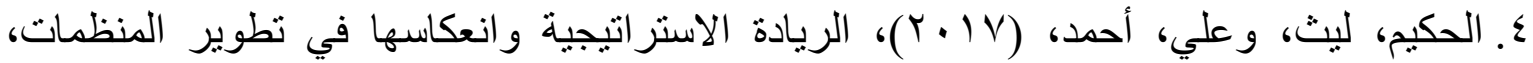
المفوضية العليا المستقلة للانتخابات أنموذجاً، مجلة الغري للعلوم الاقتصادية والإدارية، كلية

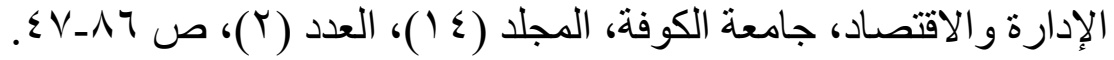

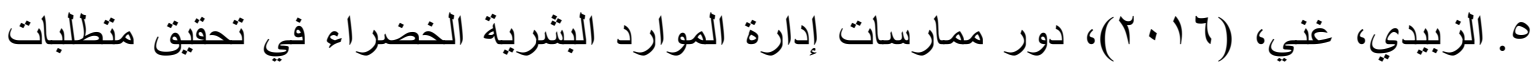
المواطنة البيئية، بحث مبداني في الثركة العامة للزيوت النباتية، جامعة بغداد، دجلة مجلة العلوم

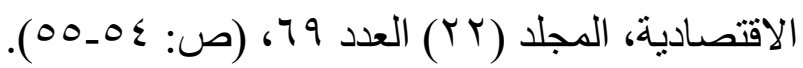

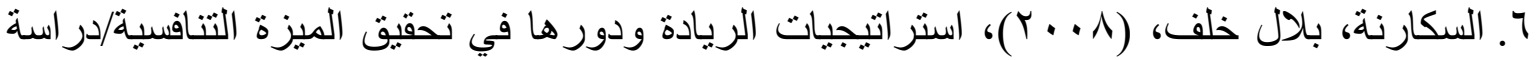

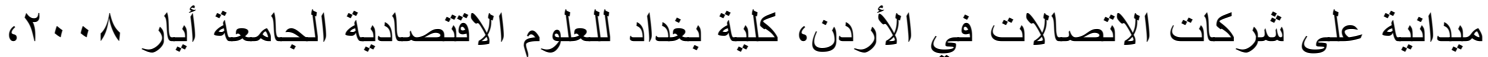

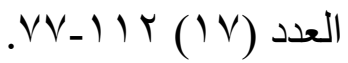




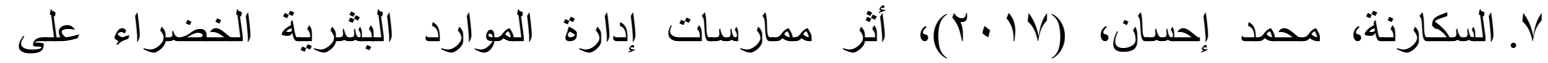

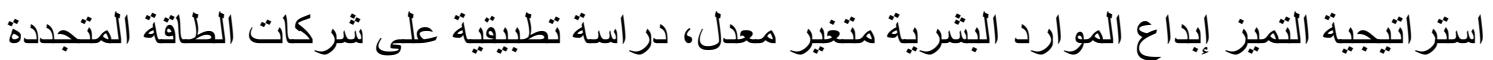

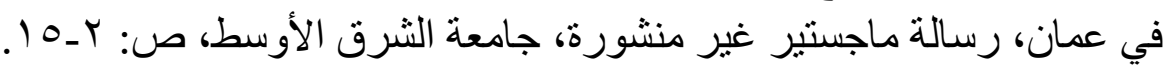

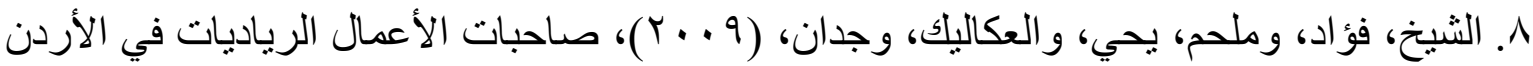

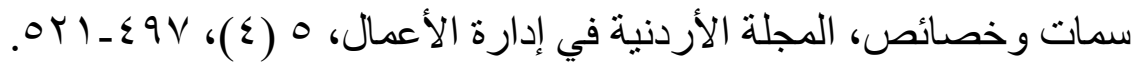

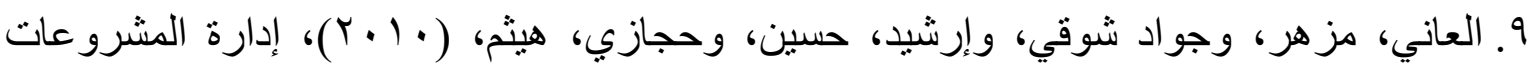

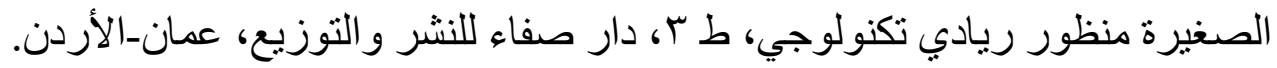

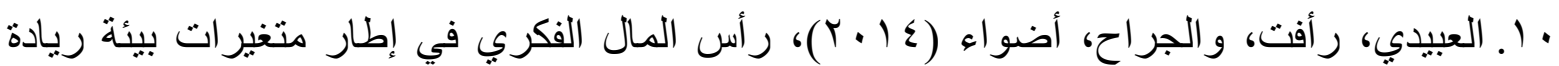

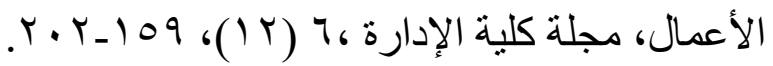

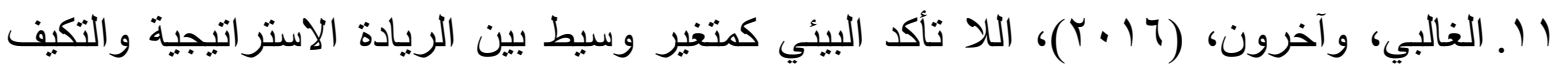

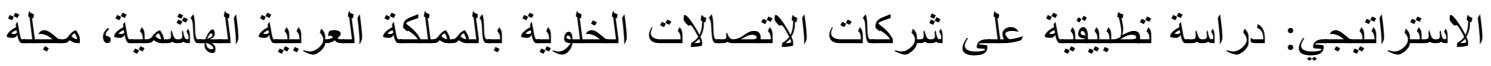

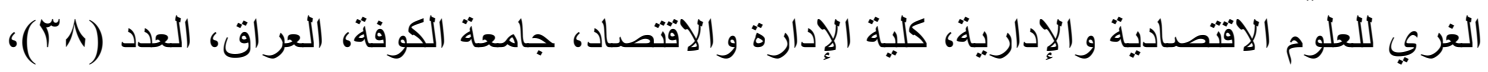

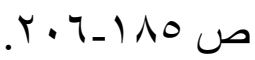

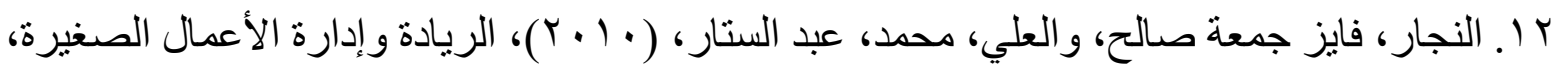

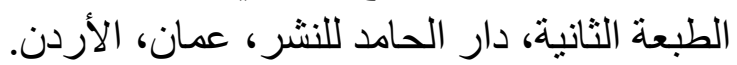
ثانياً. المصادر الأجنبية:

1. Ahmad, S., (2015), Green human resource management: policies and practices. Cogent Business \& Management, 2 (1): 1-55.

2. AL- Khalifah, Bashayer, (2014), Entrepreneurial leadership in Kuwaiti Privates Firms, thesis, Doctor of business management, University of Sterling.

3. Arulrajah, A. Anton, Opatha, Nawaratne, (2015), Green Human Resource Management Practice, 2015, pp.4-28.

4. Baum Matthias, Sterzing Anke and Alaca Neslim, (2016), Reactions towards diversity recrument and the moderating influence of the recruiting firm country -oforigin', Journal of Business Research.

5. Berrone, P., \& Gomez-Mejie, L.R., (2009), Environmental performance and executive compensation: An integrated agency-institutional perspective. Academy of Management Journal, 52,103-126.

6. Cherian, J \& Jacob, J., (2012), a Study of Green HR Practices and Its Effective Implementation in the Organization: A Review. International Journal of Business and Management, 7 (21): 25.

7. Clark, B. R., (2004), Delineating the Character of the Entrepreneurial University. Higher Education policy. Vol. 17, No.4 pp.355-37.

8. Deepika, J., (2016), Green HRM: An Effective Tool to attain \& maintain Competitive Advanced Research in Engineering \& Management (IJAREM), pp: 14-16.

9. Dess, Gregory G, Lumpkin, G.T. \& Eisner, Alan B., (2007), Strategic Management: Creating Competitive Advantage, McGraw- Hill, Barded.New York, USA.

10. Forman, M., \& Jorgensen, S., (2001), the social shaping of participation of employees in environmental work within enterprises-Experiences from a Danish Context. Technology Analysis \&Strategic Management, 13, 71- 90.

11. Hitt, M.A \& Ireland, R.D, Sirmon, D.G., \& Trahms, C.A., (2011), Strategic Entrepreneurship-Creating New Mindset: Strategic Management Society, Research and Markets. 
12. Jose Dornelas, Sergio Postigo, Dante Martineli, Debbie Setuai, Corporate Entrepreneurship: The case of Brazil \& Argentina, www.jcesi.edu.co/ciela/anteriores/papers/emcor/2.pdf,2003,p2.

13. Jyotsne Sethi, Lesson: Entrepreneur \& Entrepreneurship، (2005), p5.

14. Kanika Sharma Conceptualization of Green HRM \& Green HRM practices: Commitmet to Enveronment Sustainability, (2016) pp: 8-9.

15. Kuratko, Donald F \& Morris, Michael H, Corporate Entrepreneurship A Critical challenge for Educators and Researchers, Entrepreneurship Education and Pedagogy, Vol.1(1), 2018.

16. Kuratko, Donald F., (2007), Entrepreneurial Leadership in the 21st Century: Guest Editor's Perspective, Journal of Leadership and Organizational Studies, Vol.13.No.4, pp.1-11.

17. Mandip, G., (2012), Green harm: People management commitment to environmental sustainability. Research Journal of Recent Sciences, 1, 244-252.

18. Mishra Pavitra, (2017), Green human resource management: A framework for sustainable organizational development in an emerging economy", International Journal of organizational Analysis, Vol.25 Issue: 5, pp: 762-788.

19. Nejati Mehran, Rabiei Soodabeh and Jabbour Charbel Jose Chiappetta, (2017), Envisioning the invisible : Understanding the synergy between green human resource management and green supply chain management in manufacturing firms in Iran in light of the moderating effect of, pp: 165 .

20. Neto Angelo Saturnino, Jabbour Charbel Joose Chiappetta and Jabbour Ana Beatriz Lopes de Sousa, (2014), Green training supporting eco-innovation in three Brazilian companies; practices and levels of integration, Industrial and commercial Trinning, Vol.46 Iss7 pp.387-392.

21. Nijhawan, G., (2014), Green HRM-A requirement for sustainable Organization. Paripex- Indian Journal of Research, 69-70.

22. Norton, T.A.; Zacher, H.; Parker, S.L.; Ashkanasy, N.M., (2017), bridging the gap between green behavior/oralintentions and employee green behavior: The role of green psychological climate. J.Organ. Behav., 38, 996-1015.

23. Nuh, Milad Malko (Green Human Resource Management Practices Effect on Sustainability) an unpublished thesis of the tishk international university (2020).

24. Patil, Jayashree. Sarode A P., (2018), Green Human Resource Management: Role of HR Managers to Achieve Sustainability, International Journal of Creative Research Thoughts, Volume 6, Issue 1 January. 528.

25. Peerzadah, S Ahmad \& Mufti, Sabiya and Nazir, Ah, (2018), Green human resource management: A Review. International Journal of Enhanced Research in Management \& Computer Applications, Vol.7 Issue 3, pp: 790-795.

26. Quick MBA, Entrepreneurship, (Internet Center for Management \& Business Administration, inc, (2007), p55.

27. Robbins, P. Stephen \& Decenzo, David.A. \& Coulter, Mary, (2015), Fundammentals of Management: Essential Concepts and Application. 9rd Ed,Pearson Education Limited, England.

28. Robert. D. Histrich. Entrepreneurship.Fifth Edition, (2002), MC Graw- Hill higher Education. London. 